\title{
Archaeological and Historical Investigations at the Valenzuela Ranch, Dimmit County, Texas
}

Anne A. Fox

I. Waynne Cox

Follow this and additional works at: https://scholarworks.sfasu.edu/ita

Part of the American Material Culture Commons, Archaeological Anthropology Commons, Environmental Studies Commons, Other American Studies Commons, Other Arts and Humanities Commons, Other History of Art, Architecture, and Archaeology Commons, and the United States History Commons

Tell us how this article helped you.

This Article is brought to you for free and open access by the Center for Regional Heritage Research at SFA ScholarWorks. It has been accepted for inclusion in Index of Texas Archaeology: Open Access Gray Literature from the Lone Star State by an authorized editor of SFA ScholarWorks. For more information, please contact cdsscholarworks@sfasu.edu. 


\section{Archaeological and Historical Investigations at the Valenzuela Ranch, Dimmit County, Texas}

\section{Creative Commons License}

\section{(c) (1) \&}

This work is licensed under a Creative Commons Attribution-NonCommercial 4.0 International License 


\section{ARCHAEOLOGICAL AND HISTORICAL INVESTIGATIONS \\ AT THE VALENZUELA RANCH, DIMMIT COUNTY, TEXAS}

Anne A. Fox and I. Waynne Cox

With an Appendix by

Thomas R. Hester

Center for Archaeological Research The University of Texas at San Antonio Archaeological Survey Report, No. 126 



\section{ABSTRACT}

In early 1983, an archaeological crew from the Center for Archaeological Research, The University of Texas at San Antonio, conducted a survey and testing program at site 41 DM 65 on the Valenzuela Ranch in Dimmit County, Texas. The results of the field work, analysis of artifacts recovered during restoration of a stone house on the site, and archival research in Dimmit, Webb, and Bexar Counties are reported. Conclusions are drawn as to the ranch's original and subsequent ownership, the approximate date of construction of the house, and its various uses through the years. 


\section{TABLE OF CONTENTS}

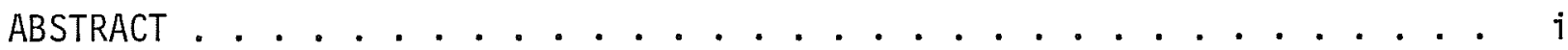

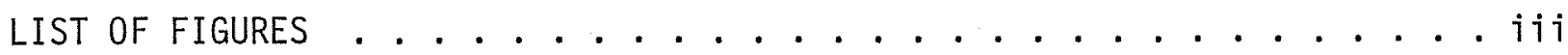

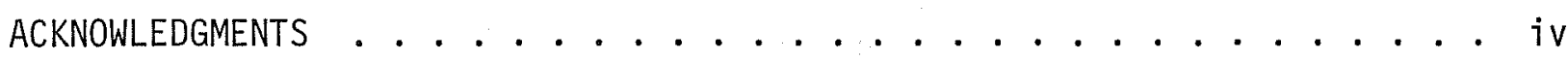

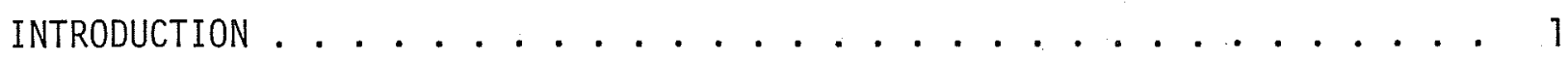

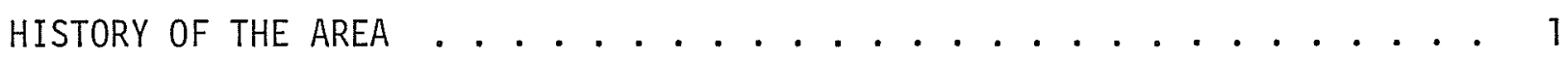
HISTORY OF THE VALENZUELA RANCH ................ 2 ARCHAEOLOGICAL INVESTIGATIONS ...................... 6 Field Work ....................... 8 THE ARTIfActual EVIDENCE . . . . . . . . . . . . . 17 Artifacts Associated with the Construction of the Ranch House . . . . . . 17 Artifacts Associated with the 0ccupants of the Ranch House . . . . . . 18 Food and Drink ................... . . 18 Housekeeping ................... . . 26

Personal Belongings . . . . . . . . . . . . . . 26

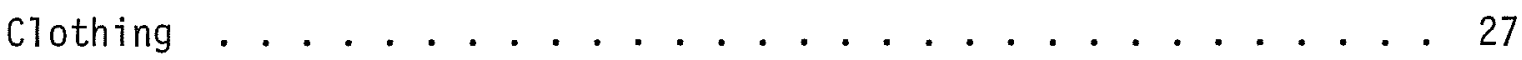

Ranching Equipment ............... . . 30

Tools....................... . . . 30

Machinery .................. . . . 30

Horse and Wagon Hardware ............. . . 30 DISCUSSION . . . . . . . . . . . . . . . 32

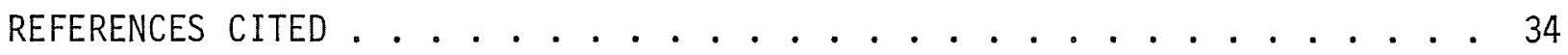
APPENDIX I. BIOGRAPHIES ........................ 39 APPENDIX II. NOTES ON PREHISTORIC ARCHAEOLOGY AT PILONCILLO RANCH, SOUTHERN TEXAS (Thomas R. Hester) ........ 44 


\section{LIST OF FIGURES}

1. Location of Original Valenzuela Ranch ............. 3

2. Railroads and Freight Road in Relation to the Valenzuela Ranch . . 5

3. Photographs of Ranch House and 01d Corral . . . . . . . . . 7

4. Map of Valenzuela Ranch .................. 9

5. Valenzuela House Site Before Restoration . . . . . . . . . . 11

6. Photographs of Archaeological Investigations . . . . . . . . 12

7. South Wall Profile, Unit 3 .............. 13

8. South Wall Profile, Trench 1 . . . . . . . . . . . 15

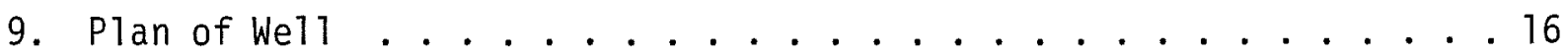

10. Construction and Food Storage Artifacts . . . . . . . . . . 21

11. Food Preparation and Consumption ............ . 23

12. Food Serving Vessels, Housekeeping and Personal Articles . . . . . 24

13. Personal Articles, Medicine, Clothing, and Harness Buckles . . . . 29

14. Horse, Wagon, and Ranching Hardware . . . . . . . . . . . 31

15. Artifacts from Piloncillo Ranch Collection .......... 45 


\section{ACKNOWLEDGMENTS}

The authors would like to express their gratitude to Bruce F. Harrison and Dan J. Harrison II I of Houston, Texas, for their many kindnesses and enthusiastic interest in the history of their ranch and its intriguing stone house. The numerous details and arrangements necessary to put an archaeological crew into the field were greatly aided by A. E. Woodard, General Manager of the Harrison Interests. The enthusiastic help and cooperation of architect Arthur J. Willrodt is gratefully remembered and acknowledged. Restoration contractor Jim Marmion of Asherton was most interested and helpful in providing information and loaning needed equipment.

Research efforts were greatly aided by consultations with local historian Laura Tidwell of Carrizo Springs, who shared maps and information. Dusty and Joel Rhoads graciously shared the collections of the public library at Carrizo Springs, pointed out local resource people, and entertained us during our stay. We are also particularly grateful to the County Clerks of Dimmit and Webb Counties and members of their staffs who were helpful in searching out obscure documents and suggesting new avenues to pursue.

A word of thanks is also due to Mr. Dan Mings who did the first historical research on the Valenzuela Ranch in 1976. His report was a starting point and a solid base for our continuing research.

We also wish to give credit to crew members Dennis Knepper and Paul Lukowski who enthusiastically joined in the field work and were soon caught up in the excitement of chasing down the details of the lives of Dr. Kearney and James Carr from Carrizo Springs to Laredo and back to San Antonio. We sincerely hope that everyone connected with the project derived as much fun and excitement out of this pursuit as did the archaeologists, and we wish to express our gratitude for the opportunity. 


\section{INTRODUCTION}

On the bank of a dry creek bed near the southern boundary of Dimmit County stands a sturdy, five-room stone building. The names of those who built it, when and for what purpose, have long been forgotten. As is often true, a few local traditions persist--it was a sheep ranch headquarters, a stop on a freight line, a stage station, and a gathering place for cattle drivers.

Natural curiosity and an affinity for restoring historic houses led the owner, Dan J. Harrison, Jr., in 1976, to embark on plans for the restoration of this old structure. Quite correctly, he first contracted with a historical researcher to try and determine when and by whom the house was built. The resulting report (Mings 1976) traces the ownership of the property along with the history of the area from Spanish Colonial times to the present, including Indian raids and depradations of Mexican bandits, the rise of the local ranching industry, and the location of roads and railroads across the general area. While he felt strongly that the building predated Anglo settlement in the county in the $1860 \mathrm{~s}$, Mings was unable to prove this by the historical records (ibid.:34).

After Mr. Harrison's death, his sons, Dan J. Harrison III and Bruce F. Harrison, carried on with the restoration project. They hired architect Arthur J. Willrodt in 1979 to prepare drawings and supervise the restoration. Taking his clues from evidence still visible on the site, similar buildings in the vicinity of Laredo, and the tenor of Mings' report, the architect has faithfully restored the plastered walls and earthern floors. He has added a thatched roof and hardware such as were used on the border in the early 19th century.

Still curious about the possible origin of the structure, the Harrisons meanwhile contacted Dr. Thomas R. Hester, Director of the Center for Archaeological Research at The University of Texas at San Antonio (CAR-UTSA), to see if archaeological investigation might provide additional information. Following a visit to the site in 0ctober 1982, T. R. Hester and A. A. Fox suggested limited archaeological investigation, combined with mapping and further historical research. The following report is the result of research, excavations, and analysis conducted by the authors during January through March 1983.

While we were not able to find any specific mention of the construction of the Valenzuela ranch house, we have been able to reconstruct many more details of the early history of the ranch and the lives of its first owners. Combining this information with the results of the archaeological research allows us to make some positive statements about the origins of the ranch and the house that became its headquarters.

\section{HISTORY OF THE AREA}

Mings (1976) has compiled a thorough and detailed history of south Dimmit County and the role of the Valenzuela Ranch in that history. We briefly summarize his work in order to provide a proper background for our research. 
Dimmit County is situated on the northwest edge of the south Texas brasada, or brush country. The area abounds in dense thickets of cacti, thorny brush, and mesquite, especially along numerous intermittent stream valleys. While at present the area resembles a desert much of the year, in the 1860s there was permanent water in the creeks and good grazing for sheep and cattle on the uplands.

Early Spanish towns in the area included San Juan Bautista to the northwest, San Antonio to the north, and Laredo to the south. Although the main trails linking these towns passed through the area, there were no settlers in Dimmit County until after the Civil War. This was primarily because of roving bands of hostile Indians who preyed on travellers and discouraged all thought of settlement.

According to local historians (Williams 1979a:6), a small group of people moved into the northern part of the county in 1865. The town of Carrizo Springs was not actually laid out, however, until 1880, the same year the county was organized (ibid.). One of the eariy settlers of particular interest to our research was Bob Lemmons, a freed slave, who upon occasion hauled freight from Encinal to Carrizo Springs for his employer, Duncan Lammons (Wil1iams 1979a:6). It seems probable that his freight wagon usually stopped at the valenzuela Ranch on its journey. Apparently the ranch house served as a station on the freight road about 1900 (Mings 1976:21).

In 1901, the railroad entered the county, and the same year Asher Richardson developed the town of Asherton (Cook n.d.:11), thus, bringing civilization a bit closer to the Valenzuela Ranch. A prosperous irrigated farming community began to grow in the area, somewhat replacing the original county emphasis on ranching. However, soon after the founding of Catarina, bringing the world even closer to the Valenzuela Ranch, the Great Depression of the 1930s arrived and wiped out development in the area (ibid.:12-13). The farmland gradually reverted to pastureland again.

\section{HISTORY OF THE VALENZUELA RANCH}

As stated in the previous report on the Valenzuela site (Mings 1976:12), there are no existing records to indicate occupation or ownership during either the Spanish or Mexican periods. There was an early Spanish. land grant in the area, the Balconcitas (Fig. 1), stretching from the Rio Grande to Piloncillo Hill. It was granted by the Crown of Spain, in 1767, to Joaquin Galan, and held by his heirs unti1 March 13, 1872 (GLO 1887). The northwestern boundary, a line from Dos Hermanos Hills to the Piloncillo, passes some four and one-half miles to the south of the site, and only a small portion of the present Harrison Ranch is included. While the lack of documented ownership does not preclude unauthorized, or "squatter," use of the land, no indication of such has been discovered. The first recorded ownership of survey number 413 on which the Valenzuela site is located, indicates it was transferred from the Texas and New Orleans Railroad Company to Albert L. Cati in on June 30, 1861. It was then transferred by him to Dr. Thomas Kearney (see Appendix I) of Corpus Christi on March 22, 1872 (DCDR 1880 Vol. 3:6). However, for some reason the records of the Government Land Office fail to include this transaction, showing only that the land passed from the Texas and New Orleans RaiTroad Company to Thomas Kearney. The survey 
3

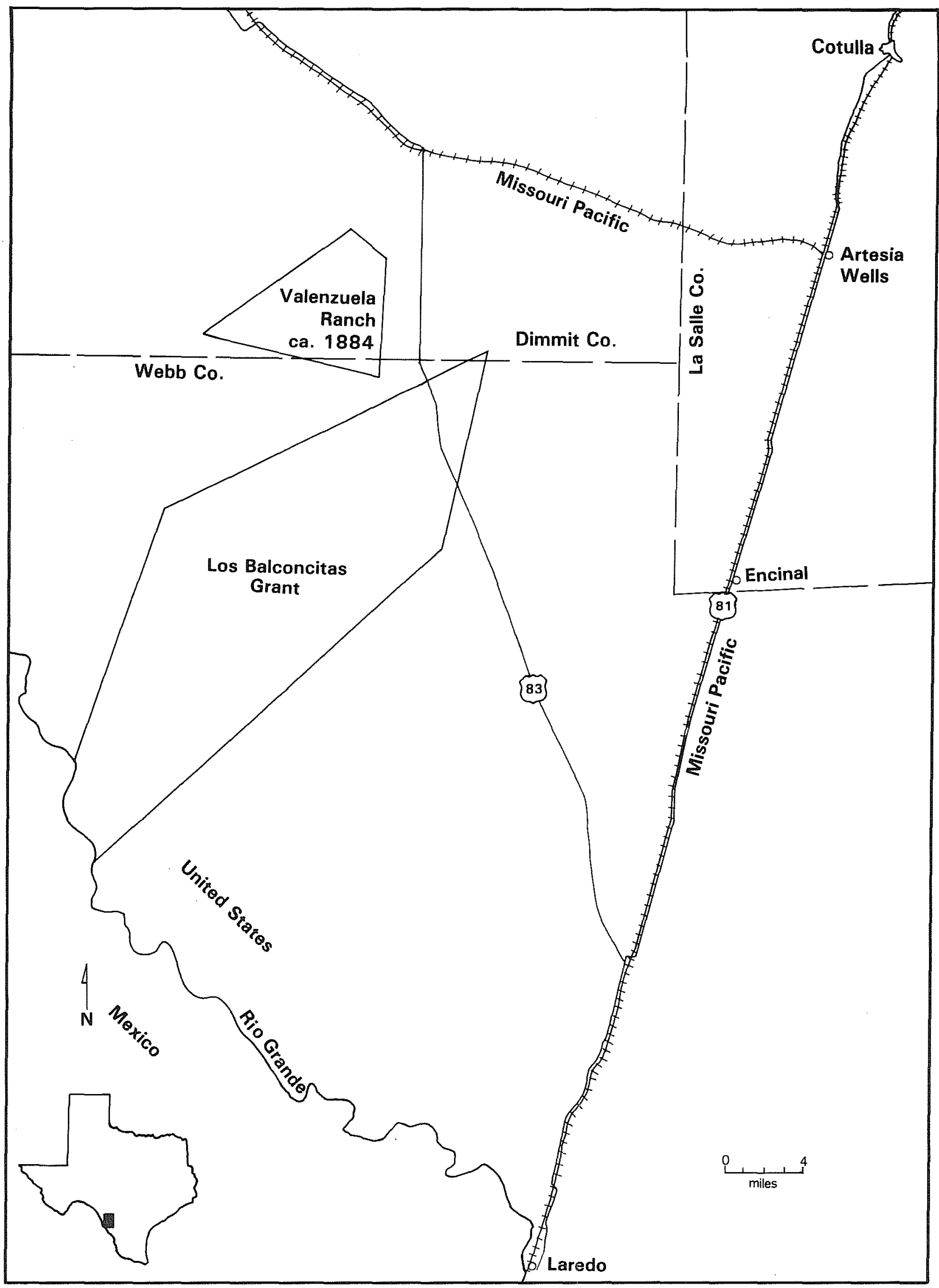

Figure 1. Location of Original Valenzuela Ranch. 
was not filed with the Government Land Office until June 12, 1872, along with a corrected survey to clarify the location of the tract. This was followed on July 10, 1875, by an additional corrected resurvey (GL0 1872, 1875). The 1ate filing date and subsequent interest as to the actual location suggest that in 1875 for the first time Dr. Kearney was taking a particular interest in the occupation and utilization of the land.

About 1875 or 1876, Dr. Kearney entered into partnership with James Carr (see Appendix I) of Laredo, and they went into the sheep-raising business. It seems likely that the stone house was built as the headquarters for the sheep ranch soon after that date. By 1880, Kearney and Carr owned considerable acreage in Dimmit and Webb Counties (DCDR 1875 Vo1. 6:137 et seq.).

At this time Texas was virtually unfenced, with cattle and sheep ranging freely. Inevitably, conflicts developed over control of water sources and pastureland. In 1881, the Texas Legislature, with pressure from the cattle industry, passed a law making it illegal to graze sheep on land belonging to another without consent (Lehmann 1969:106). This action probably prodded Kearney and Carr to purchase the adjacent tracts, which they had already been using for grazing, resulting in their holding 84,600 acres by 1883. In addition, Kearney held 68,880 adjacent acres in the Galan Grant in Webb County (DCDR 1894 Vo1. 6:137 et seq.; WCPR 1896a File No. 285: Thomas Kearney). This amount of land would have supported a flock in excess of 150,000 animals (Lehmann 1969:49).

In the early 1880s, events were taking place in San Antonio and Corpus Christi that were to have a dynamic impact on the economy of south and west Texas. In Corpus Christi, Uriah Lott had begun his Texas-Mexican Railroad (Fig. 2) to Laredo "to tap the ranch lands between the Nueces and the Rio Grande, and to divert the water-borne trade with Mexico from Brownsville to Corpus Christi" (Wilkinson 1975:363). The Iine reached Laredo in November 1881. In San Antonio, Jay Gould had begun to push his International and Great Northern Railroad toward the same terminus, in order to link up with the Mexican National Railway (Ferrocarriles Nacionale de Mexíco) from Monterrey. The International and Great National Railroad reached Laredo only a few days after the Texas-Mexican Railroad. As the International and Great Northern Railroad tracks reached stations along the developing right-of-way, passengers and freight were transferred to stages and wagons to continue their journey to the river (ibid.:365).

It was probably at this time that the road developed between Encinal and Carrizo Springs (Fig. 2), passing through the Valenzuela Ranch, and freight and passenger service began to stop at the ranch (see Mings 1976:21). This would have allowed the ranch to freight its sheep and wool to Encinal and then transship them by rail through Laredo to the Port of Corpus Christi. It would have also allowed the import of other material into the ranch. Records indicate that as early as 1895 the Laredo-Eagle Pass Road (State Highway 83) had been established, splitting the ranch into two portions (WCPR 1896a File No. 285: Thomas Kearney). Therefore, the line through the Valenzuela Ranch probably lasted only from the early 1880s to about 1900.

Beginning in 1880, a series of droughts struck south Texas. In fact, "by the $1880^{\prime} \mathrm{s}$ droughts became the rule rather than the exception . . ." (Lehmann 1969:96). This may have prompted Kearney's sale of his half interest in the 
This page has been

redacted because it

contains restricted

information. 
ranch to C. M. MacDowel1 and Thomas C. Sheldon for $\$ 65,000$ in March 1884 (DCDR 1884:64 et seq.). Also, Kearney had moved to San Antonio, where in 1881 he built a house on St. Mary's Street between Houston and Travis Streets (Morrison \& Fourmy 1881-1882; BCDR 131553). He did, however, remain connected with the sheep business, entering into a contract of partnership with Asher Richardson, in November 1886, to ". . . begin with less than 4600 ewes of the same grade ewes as may be those belonging to said Richardson . . ." to be pastured on Kearney's Galan Grant property (WCDR 1886 Vo1. 16:228). He continued to reside, off and on, in San Antonio until his death on July 3, 1896, at the age of 86 (WCPR 1896a File No. 285: Emma Schmidt).

After Kearney sold his interest in the Valenzuela Ranch to MacDowell and Sheldon, they in turn worked out a transfer of property with Carr, wherein they received the eastern half, while Carr received the western half. This may have been the first division of the ranch into the present Valenzuela and Piloncillo Ranches (DCDR 1885 Vol. 3:530). Carr apparently continued to work the Valenzuela as a sheep ranch, with his nephew, Daniel French, as foreman. At any rate, French was residing there in 1894 (WCPR 1896a File No. 285:Daniel French). Early that year, Carr apparently had a premonition of his death, for in February he transferred his sheep to his wife's name and in March dissolved his partnership of nine years with his brothers. In Apri1, he wrote his will, in June declared his homestead in Laredo, and sold the ranch to Ed Kotula (see Appendix I). He died late in the same month (WCDR 1894 Vol. 29:229, 291; Vol. 30:472; DCDR 1894 Vo1. 6:137 et seq.; and WCPR 1896b File No. 556:Carr). The ranch at the time of sale consisted of $42,28713 / 20$ acres and sold for $\$ 42,000$ (DCPR 1894 Vol. 6 : 137 et seq.).

After Kotula's death, on May 11, 1907, the ranch was administered by his son, Edward $B$. (both Edward B. and William were residing on the ranch prior to his death) until the heirs sold the ranch to J. Shugar of Dallas County in 1927 (Johnson 1914:1238; DCDR 1927 Vol. 47:343). Shugar, in turn, conveyed the 1 and to Temple Lumber Company prior to 1931. The Temple Lumber Company transferred the title to Southern Pine Company in January 1931 (DCDR 1931 Vol. 58:599). Both companies were owned by Thomas Lewis Latané Temple (see Appendix I). In 1936, Southern Pine Company sold 26,898.5 acres, including the Valenzuela Ranch, to George W. Lyles (DCDR 1936 Vol. 69:124). He in turn conveyed it to Dan J. Harrison, Jr., in 1950.

\section{ARCHAEOLOGICAL INVESTIGATIONS}

The Valenzuela site is recorded at the Texas Archeological Research Laboratory in Austin as 41 DM 65. The number 41 refers to Texas, DM to Dimmit County, and 65 indicates it was the 65 th site registered in the county when the number was issued. Structures on the site include a five-room plastered stone house (Fig. $3, a)$, a nearby shallow well dug into the sandstone bedrock, an accumulation of cattle pens (Fig. 3,b), and a stone-lined sheep dipping vat. Later structures include various sheds and metal buildings and two post-1900 houses that sit on a rise overlooking the site. Various alterations and disturbances have taken place in recent years in the area immediately surrounding the house. These have tended to alter the original relationship of the structure to its immediate environment. The Valenzuela Creek bed is located about 40 feet west of the house. 

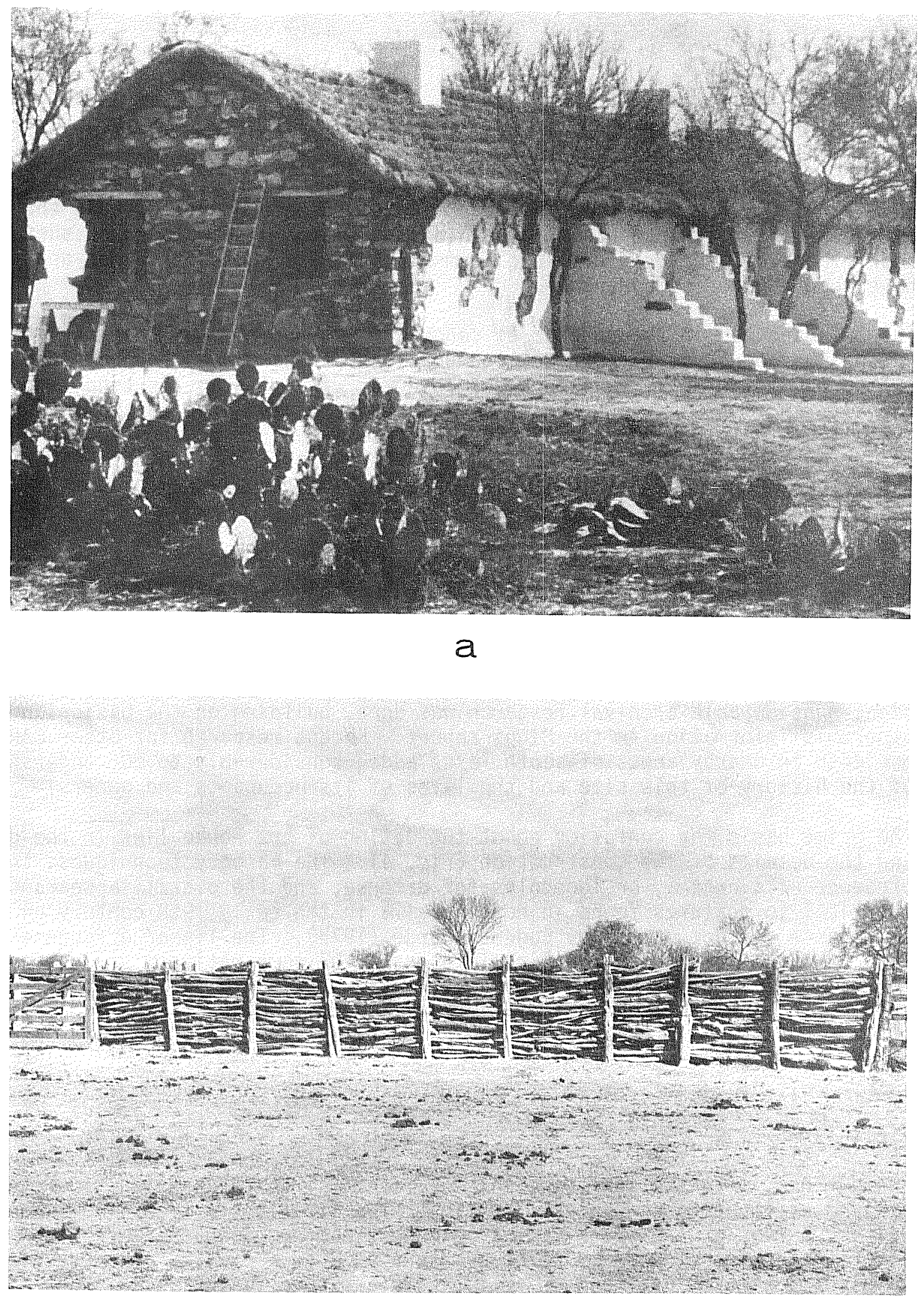

b

Figure 3. Photographs of Ranch House and Oed Corral. a, ranch house from the northwest; b, section of old corral fence incorporated into later cattle pens. 
It is now a dry, shallow drainage, its waters diverted into a series of tanks farther to the west and south by a long low berm created primarily, we understand, to protect the house from flash flooding. In an attempt to protect the structure from intruders, a chain link fence was once erected around the house. In the process, a large amount of bulldozing of the original ground surfaces took place, and the original land forms on the west and south sides appear to have been changed considerably.

The building was in the process of renovation at the time of this project. During the course of the work, large portions of the ground to the south, west, and north of the house have been trenched for water lines, air conditioning conduit, and a septic tank and field. During this work the contractor systematically saved a large collection of artifacts, separating them according to their location in respect to the house. Without this collection, we would have had a great deal more difficulty in understanding the history of the site, and we commend his foresight.

After a preliminary examination of the site and the artifacts recovered, we suggested that archaeological testing should establish once and for all the span of occupation, particularly on the relatively undisturbed east side of the house (Fox 1982). In January 1983, we initiated a project to survey the area around the site, conduct test excavations in the vicinity of the house and the well, and produce a map of the site including al1 historic features. In addition, considerable archival research was done, building on the basic land ownership information in the Mings report. Recent research for other CAR projects in nearby areas of south Texas added considerably to our understanding of the history of this site and the lives of its occupants and owners.

The prime basis for confusion about the dating of the house lies in the design and the details of its construction (Fig. 4). The masonry techniques, the presence of troneras, or loopholes for defense, and the overall appearance are identical to features found in houses built in the early 19 th century on the Rio Grande and documented by Eugene George (1975). The linear arrangement of the rooms, the design of the fireplaces, and the comparatively small size of the individual rooms call to mind early 19 th-century houses in the San Antonio area (A. A. Fox, personal observation). Despite these tantalizing details, a11 the artifactual evidence appeared to point to a construction date in the last quarter of the 19 th century.

Field Work

The authors, with the assistance of one Technical Staff Assistant from the CAR, arrived at the site on January 10, 1983. The first activity was to conduct a walking survey of the creek valley both upstream and downstream from the site covering an area of perhaps three quarters of a square mile. We were disappointed to find no evidence of a lime kiln anywhere in the vicinity despite our observation of abundant lime in the mortar, plaster, and whitewash used in the construction of the house. No evidence was found of other historic buildings in the immediate area of the house and pens. However, a small house site on the hill overlooking the house contained sherds of plain white and decorated ironstone, bottle glass, sherds from a Mexican lead-glazed bowl or jar, and a piece of a porcelain doll's head scattered among fallen chimney stones. 


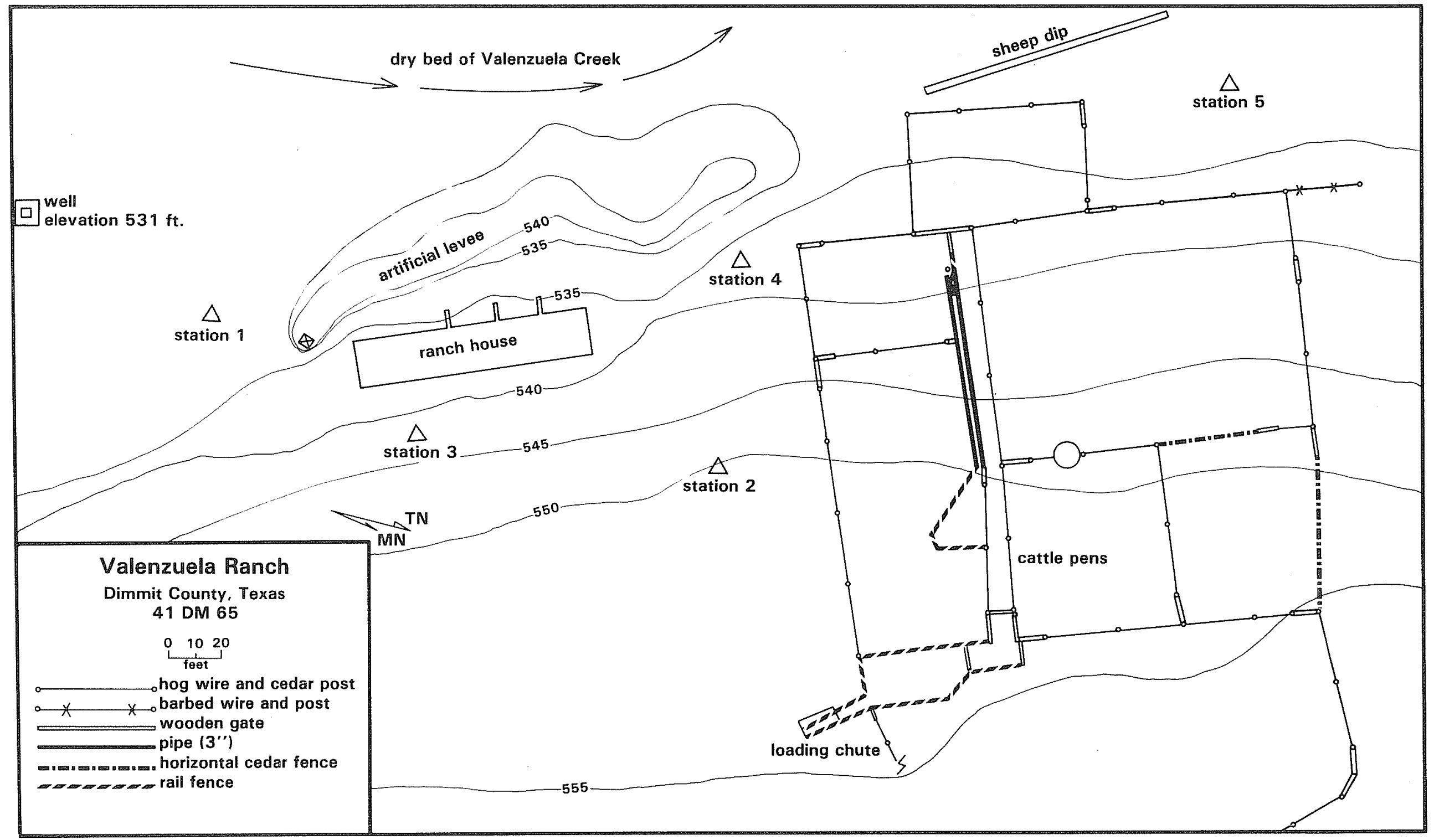

Figure 4. Map of Valenzuela Ranch. 
A detailed map of the historic structures was made using an alidade and plane table (Fig. 5). A stratification test with a post hole digger ca. 24 feet east of the northernmost door (Fig. 5) revealed that the deposits on the east side of the house consisted of about two inches of grass roots and humic soil, which overlay a 10-inch layer of tan sandy clay loam with occasional small fragments of orange ocherous sandstone. Below this the soil changed abruptiy to gray tan, containing small pieces of consolidated dark gray clay. This continued unchanged to 24 inches, at which point the testing was discontinued. No artifacts were present in any of the deposits.

Two parallel string 1 ines were laid out 11 feet and 14 feet from the east wal1 of the house ( $F i g .5$ ), and a series of three-foot squares were measured off between these lines. A one-square foot test hole was then excavated in the southwest corner of each three foot square (Fig. 6,a). The tests were numbered in sequence 1 through 6 , from north to south. Virtually the same basic stratification was found in each test, although medium-sized fragments of sandstone became more frequent as we progressed southward. Comparatively few artifacts were present, and these only in the upper six to eight inches. In order to more closely examine the stratigraphy in this area, test Unit 3 was expanded into a full three-foot square unit and excavated by stratigraphic levels. The stratigraphy in this square (Fig. 7) was typical of that found throughout the area. Level I consisted of wind-blown and washed-in soil recently deposited. (The sparse grass cover throughout the site would not be sufficient to prevent periodic episodes of redeposition of soil.) Level II had the appearance of an occupation surface of some duration. Artifacts such as small fragments of wall plaster, wire nails, small bits of bottle glass, .22 shel1s, and a contemporary glass marble found in and just below this level suggest a period of time during the present century when this was the ground surface. Small pieces of broken animal bone and mussel shell were also indicated in these deposits, hinting of the diet of the inhabitants. From the appearance of the streams in the vicinity today, it would be hard to imagine that they once had sufficent flow to nurture mussels. However, water was evidently abundant in this area in earlier times (Williams 1979a:6). The mussels could have been carried in from a larger, more permanent stream such as the San Roque Creek to the north.

The lines of demarcation between the layers of soil from this level down were vague and difficult to determine. It appears that much of the deposit has been the product of years of slope wash across the area. This build-up was noted and removed in the porch area against the house wall when the remodeling began (A. J. Willrodt, personal communication). Unfortunately, the removal of the soil over the porch area before we arrived on site eliminated evidence which might have helped to date soil deposits. The total absence of artifacts in the lower deposits is difficult to explain, unless the soils below Level II were deposited before the construction of the house.

In an attempt to associate datable artifacts with the house construction, an area at the north end of the porch floor (Fig. 5) was troweled down to a hard surface of disintegrating sandstone slabs which appeared to be the original floor. Just above and embedded in this surface were numerous wire nails and painted plaster fragments probably reflecting numerous episodes of building and rebuilding of the porch roof and disintegration and repair of the wall plaster. Five small pieces of window glass were also present. Scattered small charcoal 


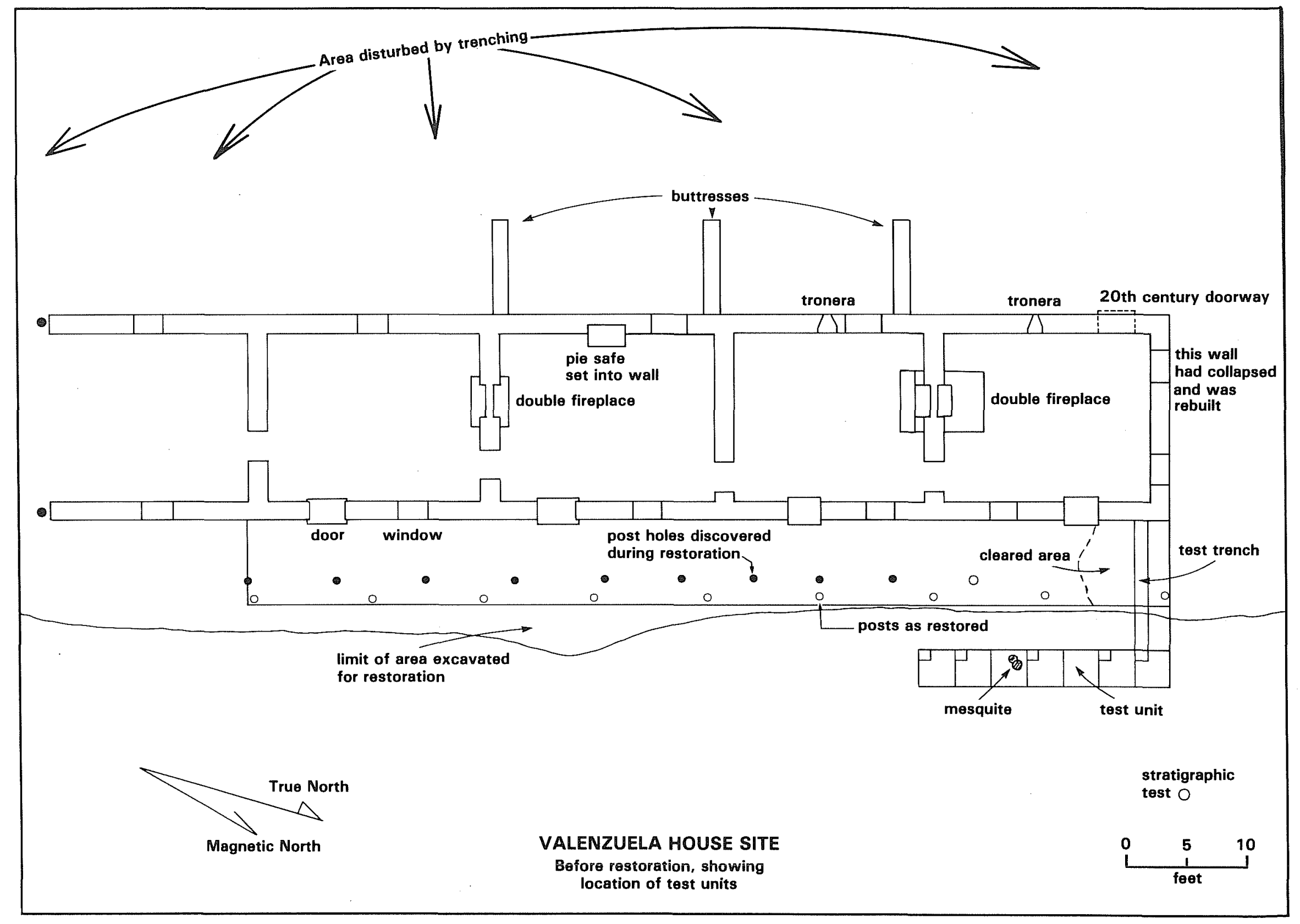

Figure 5. Valenzuela House Site Before Restoration. 


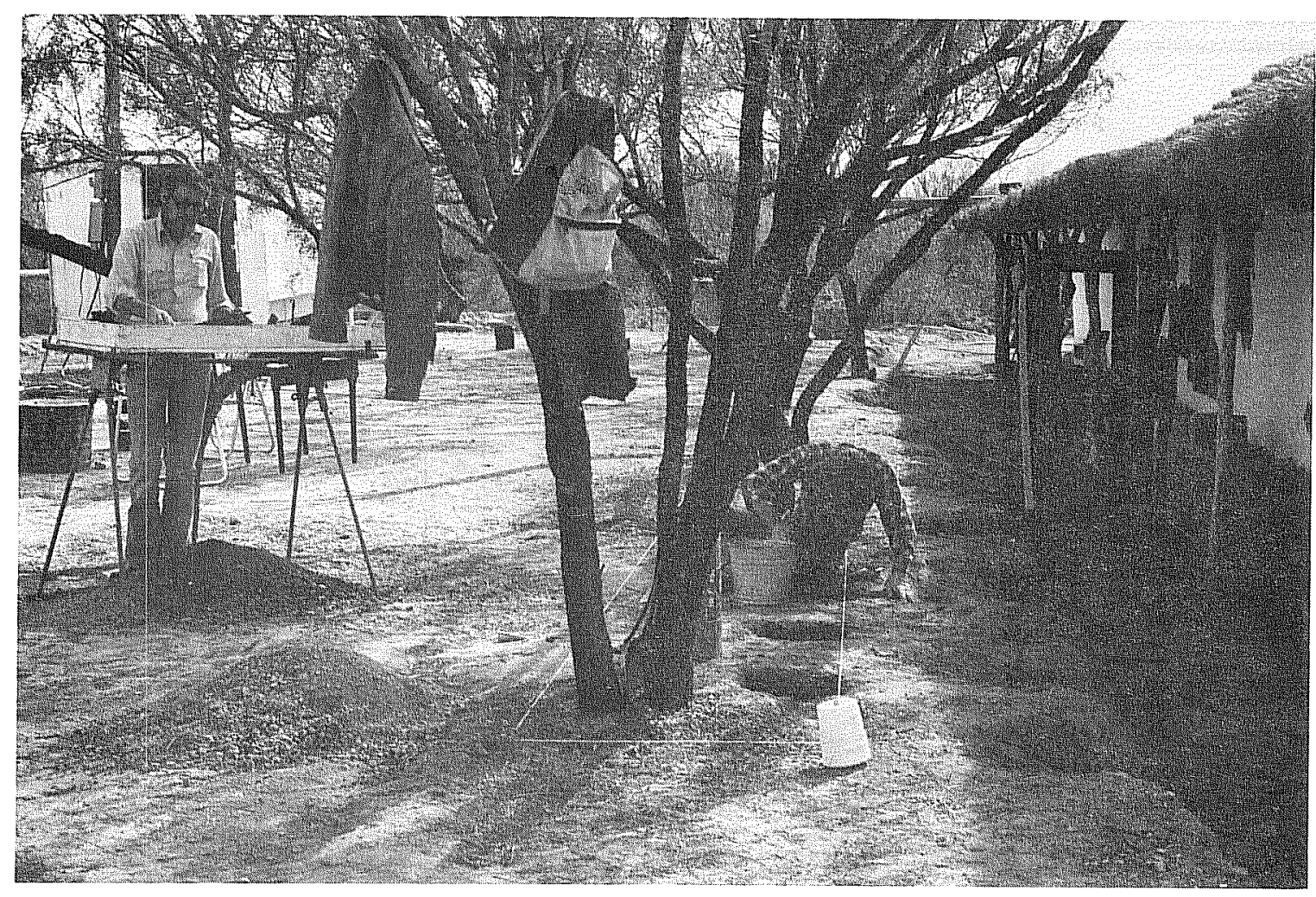

a

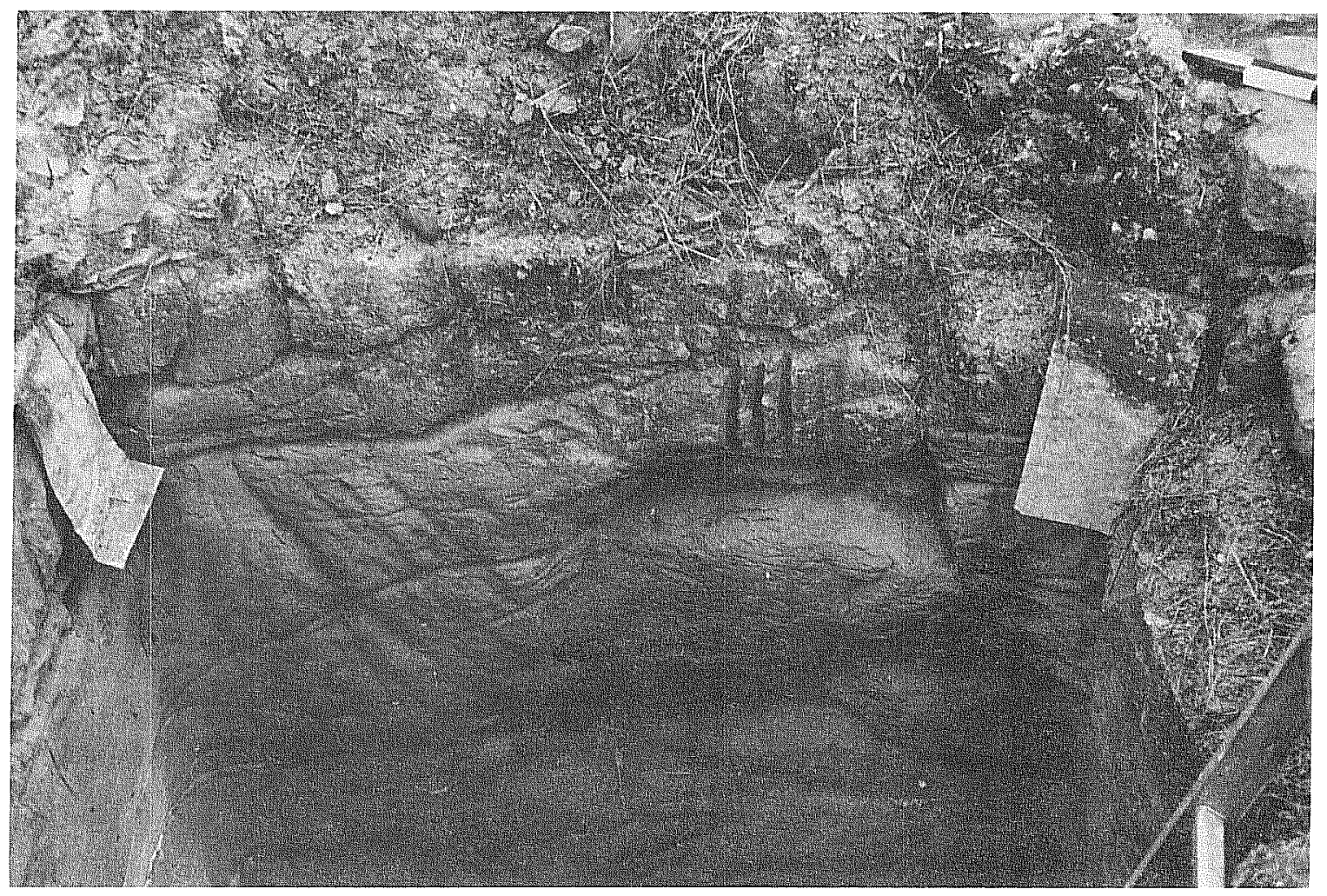

b

Figure 6. Photographs of Archaeological Investigations. a, archaeological testing on east side of ranch house; $b$, vertical grooves in sandstone on east side of we17. 


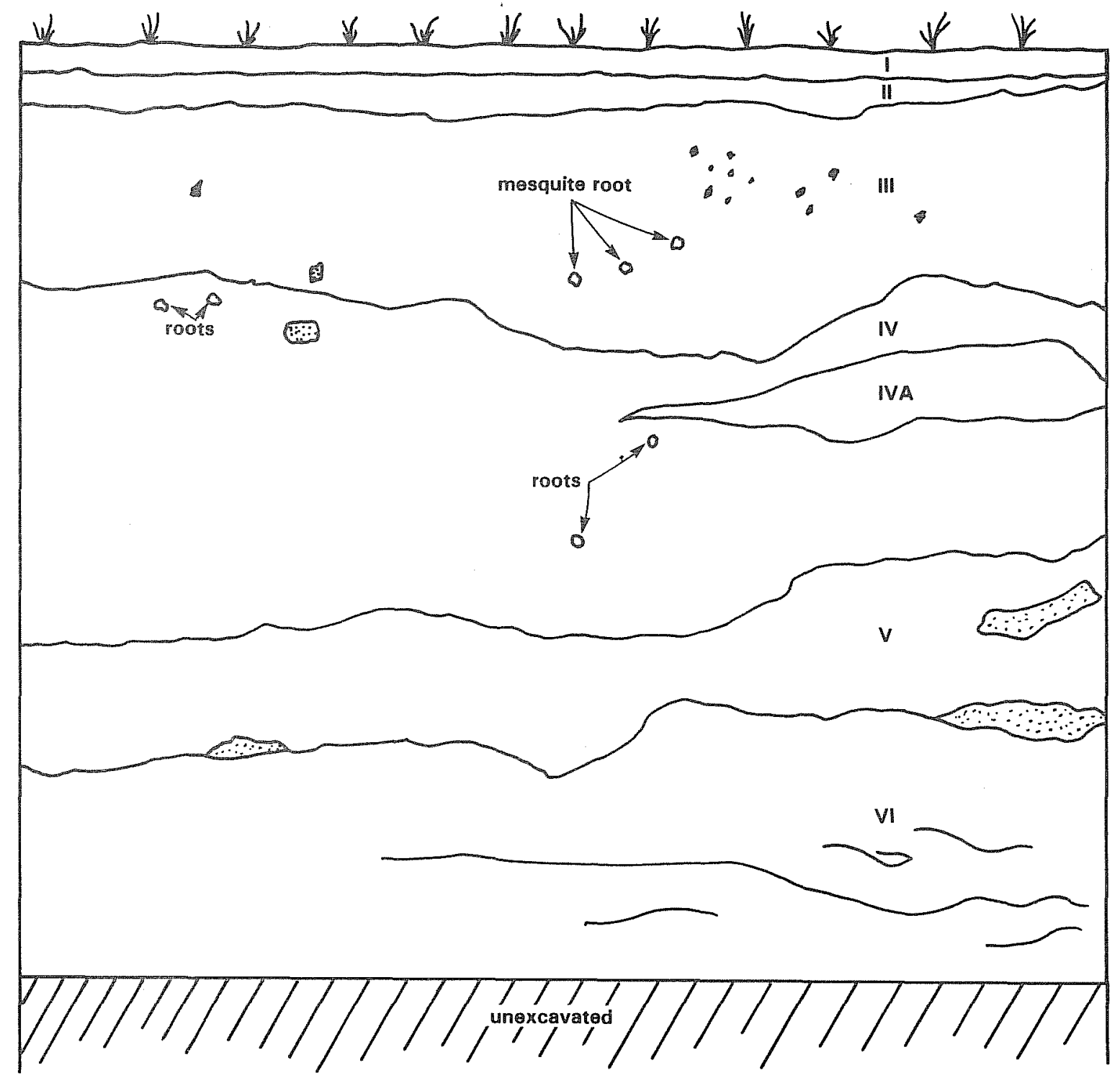

light tan top soil

II roddish ashy layer

III loose, clayey brown soil with

numerous small roots and pebbly inclusions

IV loose brown to gray clay

with white mold or mildew

liberally intermixed

IVA light tan, sandy lens

$\checkmark \quad$ light brown sandy clay

VI gray to brown clay

with orange; sandy streaks

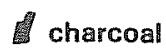

(1) sandstone

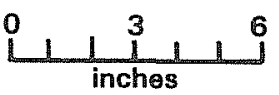

Figure 7. South wall Profile, unit 3. 
fragments were probably a product from cleaning fireplaces and/or stoves. There were also seven pieces of bottle glass and two sherds of plain white ceramic ware in this deposit, along with a few small fragments of animal bone. A two-inch-wide strip of rubber inner tube was also embedded in the sandstone surface.

In all, the materials found on the porch are in character with its late 19th century use as a passageway from the kitchen door to the outside area, probably to the back yard where most of the trash disposal appears to have taken place. For most of its early years, the house had no outside exit from the kitchen except the east door. The later installation of a door on the northwest corner of the room (Fig. 5) was probably constructed in the present century when the house was repaired for use as a hunting cabin.

Hoping to establish the relationship between the porch floor deposits and Level II in Test Pit 3, we excavated a trench between Test Pit 1 and the porch in order to observe a profile from the house to the yard area (Fig. 8). Apparently, Leve1s II, III, and IV were truncated when excavation was done for the reconstruction of the porch. Alluvium from Level I has spilled over and capped the new surface. Carefui study of the profile suggests that the interface between Levels IV and V may have been the ground surface when the house was built. If this is so, we are at a loss to explain the total absence of artifacts at this level in any of the test units excavated. Since the artifacts in Level II are similar to those found on the porch floor, it seems more likely that there was a direct relationship between these levels that was eliminated by cleaning off the porch prior to reconstruction.

An interesting artifact recovered from this trench was a length of early barbed wire (Fig. 14,h) which consists of a single wire with a flat, two-point barb. It clearly demonstrates one of the early problems with such wire, as six of the barbs have slipped from their original locations and gathered in one spot on the wire. Barbed wire fencing was not used in this area until the 1ate 1880s. Therefore, this could be some of the first fence wire used on the Valenzuela Ranch.

Attention was then turned to the well about 40 yards south of the house, in hopes of finding some indication of when it was dug and how long it was in use. The well is a roughly square hole dug through the sandstone bedrock and into the underlying gravels. The well shaft expands one to two feet in all directions below the sandstone level. It is 10-1/2 feet deep and about four feet by six feet across at the top and is surrounded by a sturdy plank fence lined around the bottom with wire mesh (Fig. 9). This arrangement has apparently kept snakes and small animals from moving into the well, as none were encountered during excavation. A three-inch diameter pipe projects from the floor of the well, evidence that the use of the well was extended after the water table had subsided below the bottom by drilling deeper and attaching a windmil1.

The grass and weeds were cleared from the area within the fence, and the soil was removed from observed stone foundations around the well head (Fig. 9). The stone foundations consisted of four blocks constructed of shaped sandstone set in sandy lime mortar, probably the base for the installation of a windmill. 


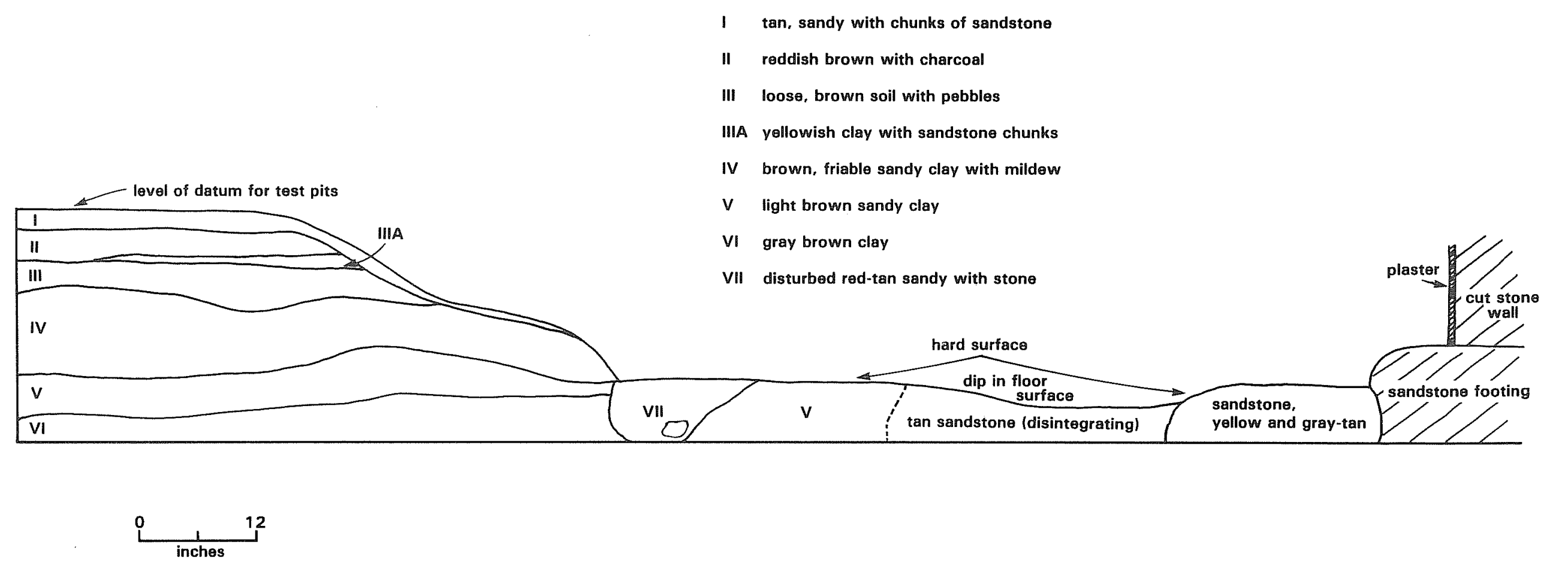

Figure 8. South wall Profile, Trench 1. 


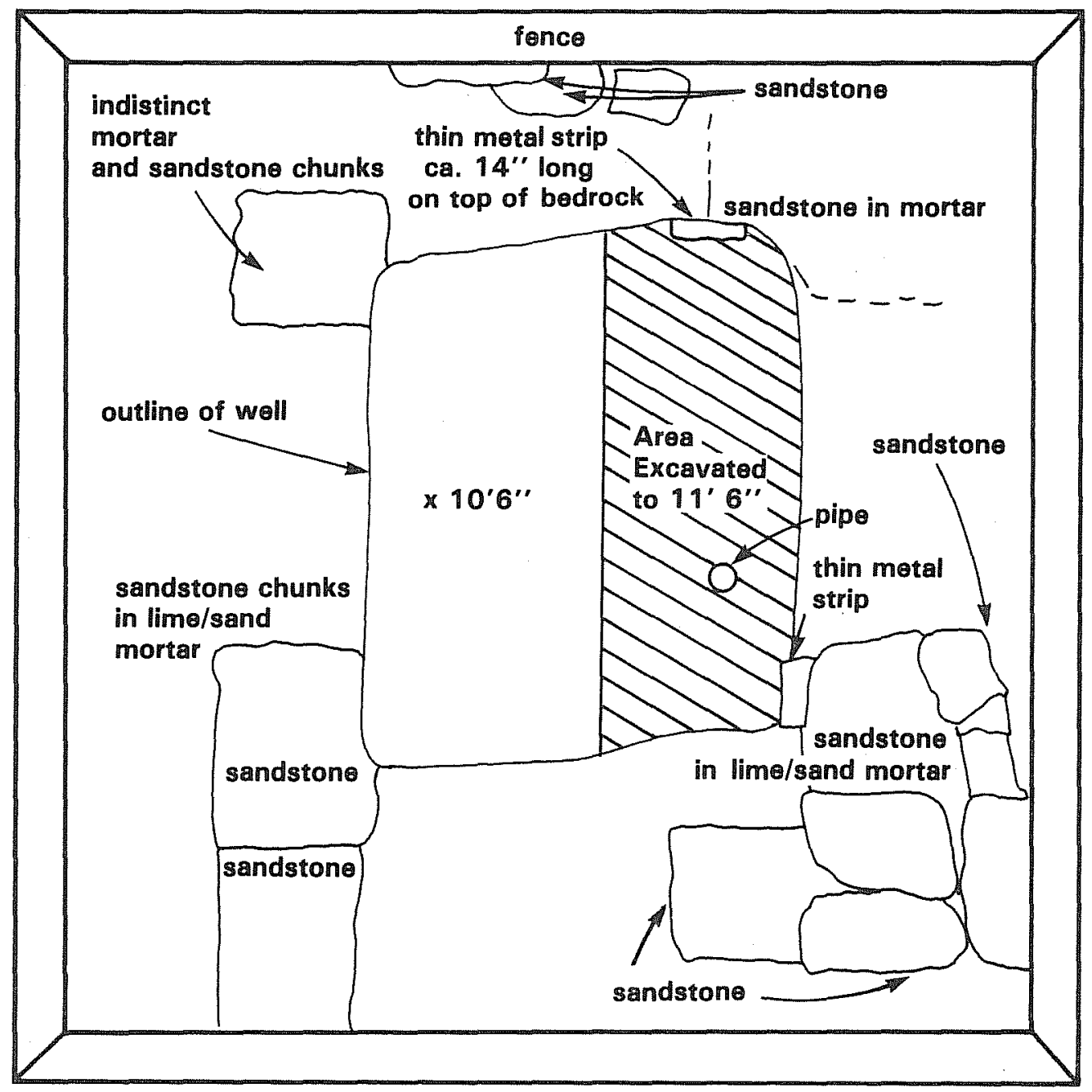

Depth of present fill in well (below SW corner post at ground surface) 10'6"

Depth of bottom of excavation 11'6"

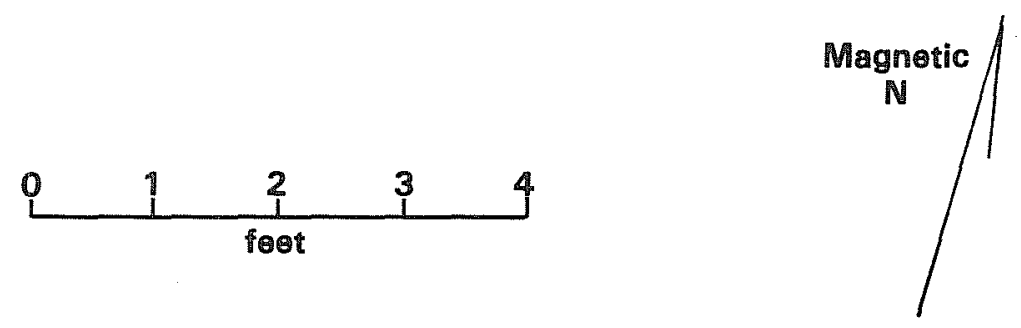

Figure 9. Plan of well. 
There are several vertical grooves near the top of the sandstone lining on the east side of the wel1, possibly worn by ropes used to draw buckets from the wel1 (Fig. 6,b).

The east half of the well was excavated to the water table at 11-1/2 feet. Fragments of a rusted tin bucket with a bale handle, a goat skul1, a handful of wire nails, and the metal parts to a windmill sucker rod were the only objects recovered. Cleaning around the edge of the well yielded a few more goat bones, fragments of glass bottles, wire nails, and four cut nail fragments. A handmade skimmer made from a sucker rod to which was attached a screen made of lightweight expanded metal lath suggests that there was still water in the well into the mid-1900s.

It is not known exactly when the well was dug. When the ranch was first organized, water was still running in the creeks throughout Dimmit County, but the supply was probably gradually diminishing. In order to have a year-round, dependable water supply a well probably soon became a necessity. Then as the water table lowered, a deeper well was drilled into the bottom, and a windmi11 was erected to pump it out.

\section{THE ARTIFACTUAL EVIDENCE}

The collection made during restoration consisted of a number of cartons of assorted glass, ceramic, and metal objects. The boxes had been carefully labelled as to the area of the grounds where they were collected, and keyed into a map which was included with the collection. At the laboratory, the artifacts were washed and catalogued, maintaining their separate provenience, and spread out on tables for analysis. After examining the collection, it was determined that there were no significant differences in terms of time period or use of artifacts between the various groupings. The artifacts were from that point on considered as one group. However, the artifact catalog has preserved the separation for future reference if necessary.

For convenience in analysis, as well as to obtain a better understanding of their implications for the history of the ranch, we have divided the artifacts into categories according to their probable use. Rather than attempting to describe each fragment of broken glass and rusted piece of metal, we have chosen whole objects or identifiable fragments which best represent the collection. These will be discussed in terms of what they reflect of the people and the operations at the ranch at the time they were in use.

Artifacts Associated with the Construction of the Ranch House

Artifacts found around an old structure often give important clues about architectural details which were once a part of the structure. Close examination of the valenzuela ranch house leads to the conclusion that it has been remodeled and changed numerous times over the years. When this sort of change is accomplished, the out-of-date, broken or no-longer-wanted hardware is usually discarded on the garbage heap, leaving clues for the archaeologist which may have escaped the restoration architect's careful study of the building itself. 
In this case, there were traces of window glass and a number of nails. The square or cut nails outnumbered the more recent wire nails by a proportion of five to one. This is about what might be expected from a structure that was built and primarily occupied before 1900. Of particular interest is a broken shutter or blind hinge (Fig. 10,a) similar to those sold by Sears, Roebuck and Company (Israel 1968:93) and Montgomery Ward and Co. (1969:385) in the 1890s. It was constructed in such a manner that the hinge locked by gravity in the open position, a point stressed in the advertising.

At some point in time the doors to the house had rim locks, which were mounted on one face of the door rather than being set into the fabric of the door itself. The ceramic handles of these locks often came loose and had to be replaced, the discards ending up in the trash. This collection contains a whole white porcelain knob (Fig. 10,e) and a broken piece of a type called "brown mineral" (Fig. 10,d), a flanged ring (Fig. 10,c) for mounting on the side of the door opposite to the lock, and a striker (Fig. 10,g) which was mounted on the door frame to receive the latch.

Two hinges are in the collection. One sturdy brass door hinge (Fig. 10,h) shows signs of having once been mounted on a green-painted door and door frame. The other of lightweight iron resembles screen door hinges of the post-1900 era (Fig. 10,i). An ornate shelf bracket bears a cut-out design (Fig. 10,f). Such brackets were popular in homes in about 1890 to 1910 . It seems rather out of place here on the frontier, perhaps reflecting an occupant's attempt to bring some of the finer things into a rather bleak, routine existence.

Possible evidence of the early appearance of electricity in the house is a broken porcelain insulator (Fig. 10,b). These were used in some of the first installations of electricity, where it was necessary to pass uninsulated wires through wooden construction.

From this we see that at some point in the early years (ca. 1880 to 1900) the valenzuela ranch house had typical appointments of a late 19th-century Texas farmhouse. There were blinds or shutters on the windows and rim locks with ceramic handles on the doors. The presence of one turn-of-the-century ceramic insulator does not necessarily indicate that the house had electricity that early, especially since there would have been no possible source of power within a reasonable distance until well after 1900 .

Artifacts Associated with the Occupants of the Ranch House

Examination of the artifacts at first produces a confusing impression of broken glass, chinaware, and chunks of rusted metal. However, after study, examination, and sorting, the following categories evolved which will help to explain their meaning.

Food and Drink

There are many interesting clues among the artifacts concerning the living and eating habits of the inhabitants. Since the kitchen is generaliy the heart of any operation involving human occupancy, we will begin there. 
Storage of food is represented by a few fragments of tin cans of post-1920 vintage (see Fontana and Greenleaf 1962:73) and fragments of canning jar 1ids (Fig. $10, j-n)$. Also represented were condiment bottles and wide-mouthed glass jars which held pickles and other food stuffs (Fig. 11,a,b). Various time periods are represented.

Also important in the late 19th-century kitchen for storage and preparation of food were stoneware crocks, jugs, and bowls. Quite a variety of these vessels is found in the collection, many originating from San Antonio potteries (Fig. $10,0-r, t)$. Crocks were used for food storage, bowls for cooling and storage of milk and milk products, and sma11-mouthed jugs for storage of various kinds of 1 iquids.

Preparation of food in the late 19th century generally involved a number of different types of cast iron hollowware griddles, pots, kettles, and frying pans. At present, large fragments of such articles are scattered about in the creek bed to the west of the house. Two handle fragments from skillets or "spiders" (three-legged, covered skillets used on the hearth) are in the collection (Fig. 11,q) along with the handle from a cast iron pot lid (Fig. 11,p).

We were able to reconstruct from numerous broken fragments a section of a yellowware mixing bowl decorated with blue bands (Fig. 11,i). Nesting sets of such bowls were sold throughout the late 19th century by various mail-order houses (Raycraft and Raycraft 1975:Plate 16) and must have been used in nearly every farmhouse kitchen. A small fragment of a lead-glazed Mexican-made bowl (Fig. 10,s) and a piece of a molcajete (Fig. 11,h) for grinding spices indicate influence from the border area. One fragment of a vessel with a bulbous body and straight, cylindrical neck has a thin lead glaze on the outside only. In shape and size, it suggests a Mexican chocolatera (chocolate pot). However, this is a wheel-made vessel, whereas chocolateras are generally molded, and are glazed on the inside.

Most of the liquids consumed on the site came from glass bottles. These range in age from early 1880s' soda, whiskey, beer, and wine bottles to more recent Seven-up, Ginger Ale, and milk bottles (Fig. 11,c-g,j,k). Bottle makers' marks indicate contemporary bottles, at least, were coming from both the United States and Mexico. Consumption of the contents of this glassware in the late 19th century was from molded glass tumblers with banded rims and heavier tumblers with hexagonal or octagonal bases (Fig. 11,1-n). Identical tumblers were in use throughout south Texas and San Antonio at that time (see Fox and Livingston 1979:57; Schuetz 1970:10; and Fox 1978:59). Also, probabiy in use about this same time was a pressed glass bowl with a floral design (Fig. 11,0).

By far the majority of the ceramics found on the site consisted of thick white "chinaware" or ironstone (Fig. 12,a-c,f) which was universally popular throughout south Texas after the Civil War. Made both in England and in the United States, this sturdy ware held up well against the rigors of rural farm and ranch households. Two identifiable manufacturers' marks help to confirm the dating of the majority of the artifact deposits (Fig. 12,d,e). A plate was made by Cartwright Brothers of East Liverpool, Ohio, sometime between 1880 and 1900 (Thorn 1947:121). A saucer marked "Wood \& Son, England, " came from the Trent and New Wharf Potteries in Burslem, England, which were in operation 
Figure 10. Construction and Food Storage Artifacts.

a, shutter hinge;

$b$, porcelain insulator;

c, door lock part;

d, "brown mineral" door knob;

e, white porcelain door knob;

$f$, shelf bracket;

g, door lock striker;

$h$, brass door hinge;

$i$, screen door hinge;

$j$, food storage bottle;

k, canning jar 1id, mi 1k glass, "White Crown Cap, Pat-11-22-10";

1, canning jar lid, milk glass, plain;

m, canning jar lid, clear glass;

$n$, food storage bottle;

0 , lead-glazed jar;

$p$, stoneware milk pan rim, Albany slip;

$q$, stoneware jug neck, Albany slip;

$r$, stoneware crock, Bristol glaze, probably Elmendorf pottery;

$s$, lead-glazed bowl;

$t$, stoneware jug handle, green brown slip, Mayer pottery. 


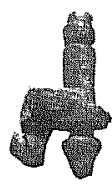

a

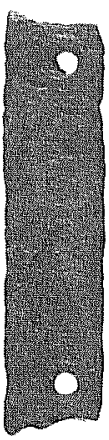

9

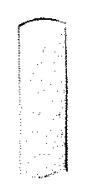

b

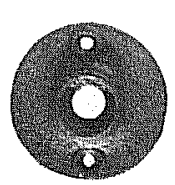

C

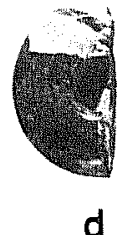

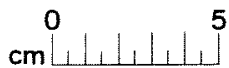
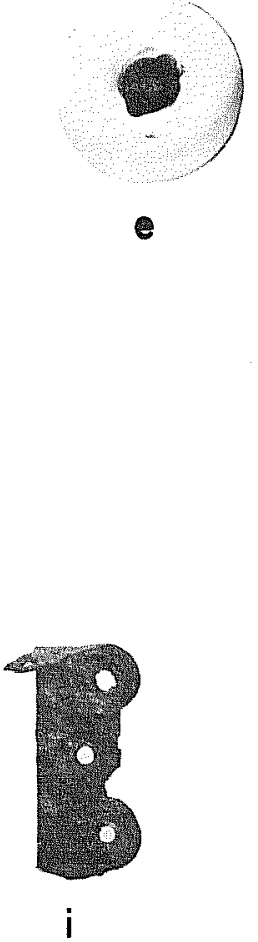

h

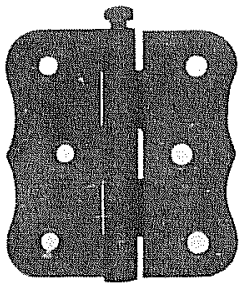

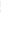
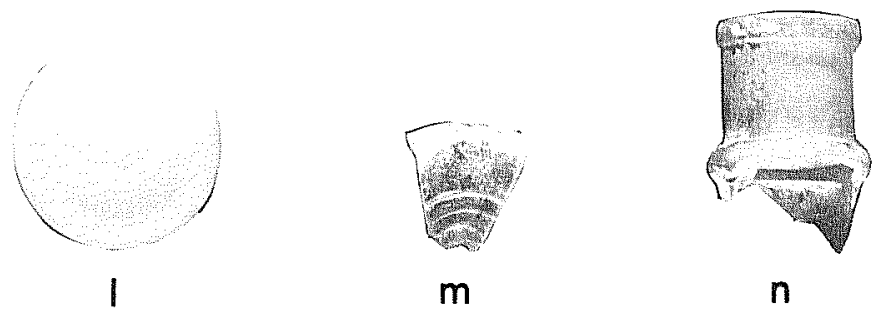

n
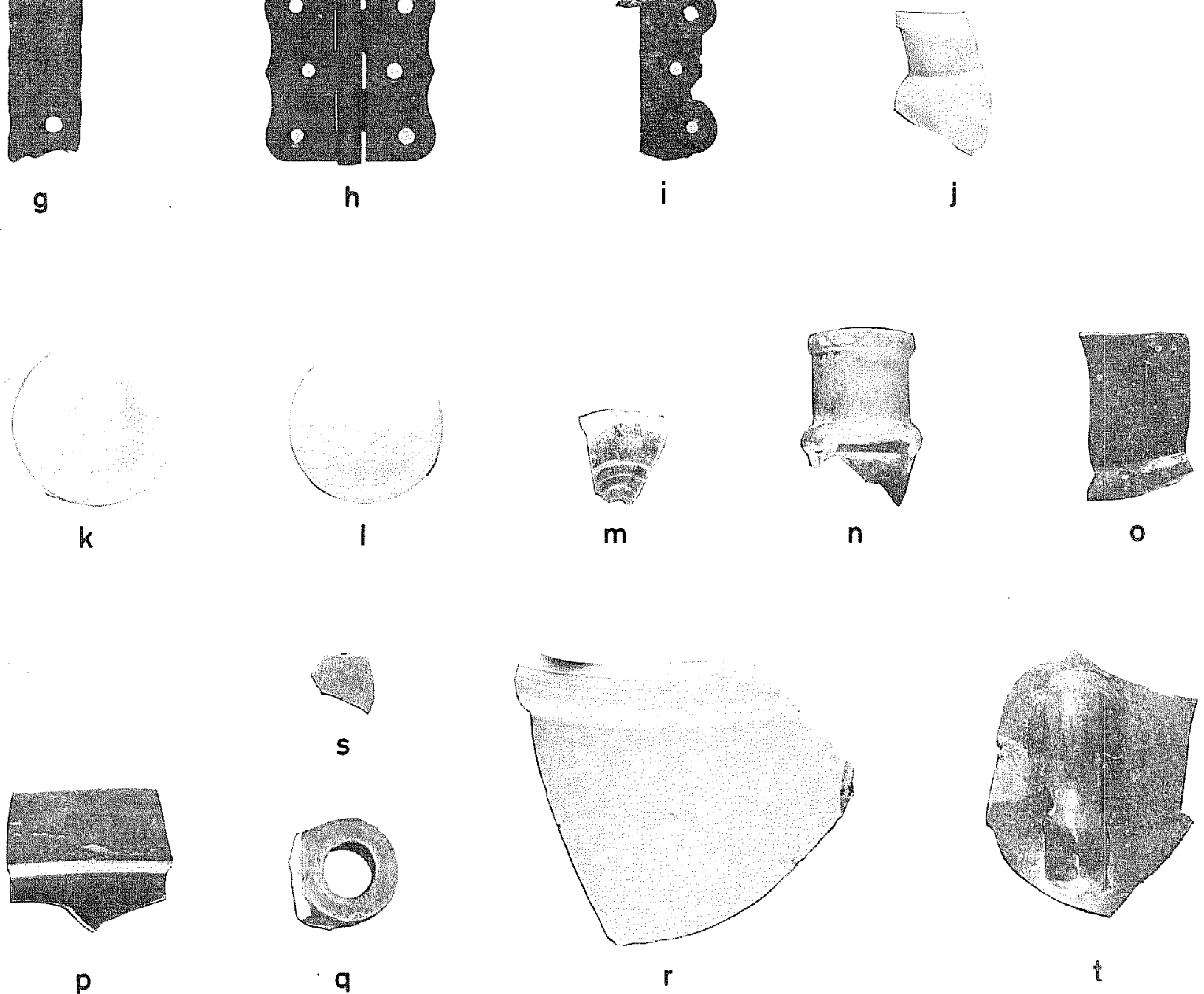

$p$

$q$ t 
Figure 11. Food Preparation and Consumption.

a, condiment bottle, screw top, clear;

b, condiment bottle, corker, aqua;

c, whiskey bottle, corker, clear;

$d$, wine bottle, olive green (?);

e, beer bottle base, brown, Atlantic Bottle Company, 1918 to 1930 (Toulouse 1971:28);

$f$, milk bottle neck, clear;

$\mathrm{g}$, beer or whiskey bottle neck, brown;

$h$, ceramic grinding bowl or molcajete, lead glazed;

$i$, yellowware mixing bow1;

$j$, bottle base, contemporary Mexican mark;

$k$, beer or whiskey bottle, brown;

1 , molded glass tumbler, clear;

$m$, molded glass tumbler base, clear;

$n$, glass tumbler with banded rim;

0 , pressed glass bowl, clear;

$p$, pot lid handle, cast iron;

$q$, skillet handle, cast iron;

$r$, iron fork handle;

$s$, silver-plated teaspoon;

$t$, unidentifiable tablespoon;

$u$, "Alaska" tablespoon. 


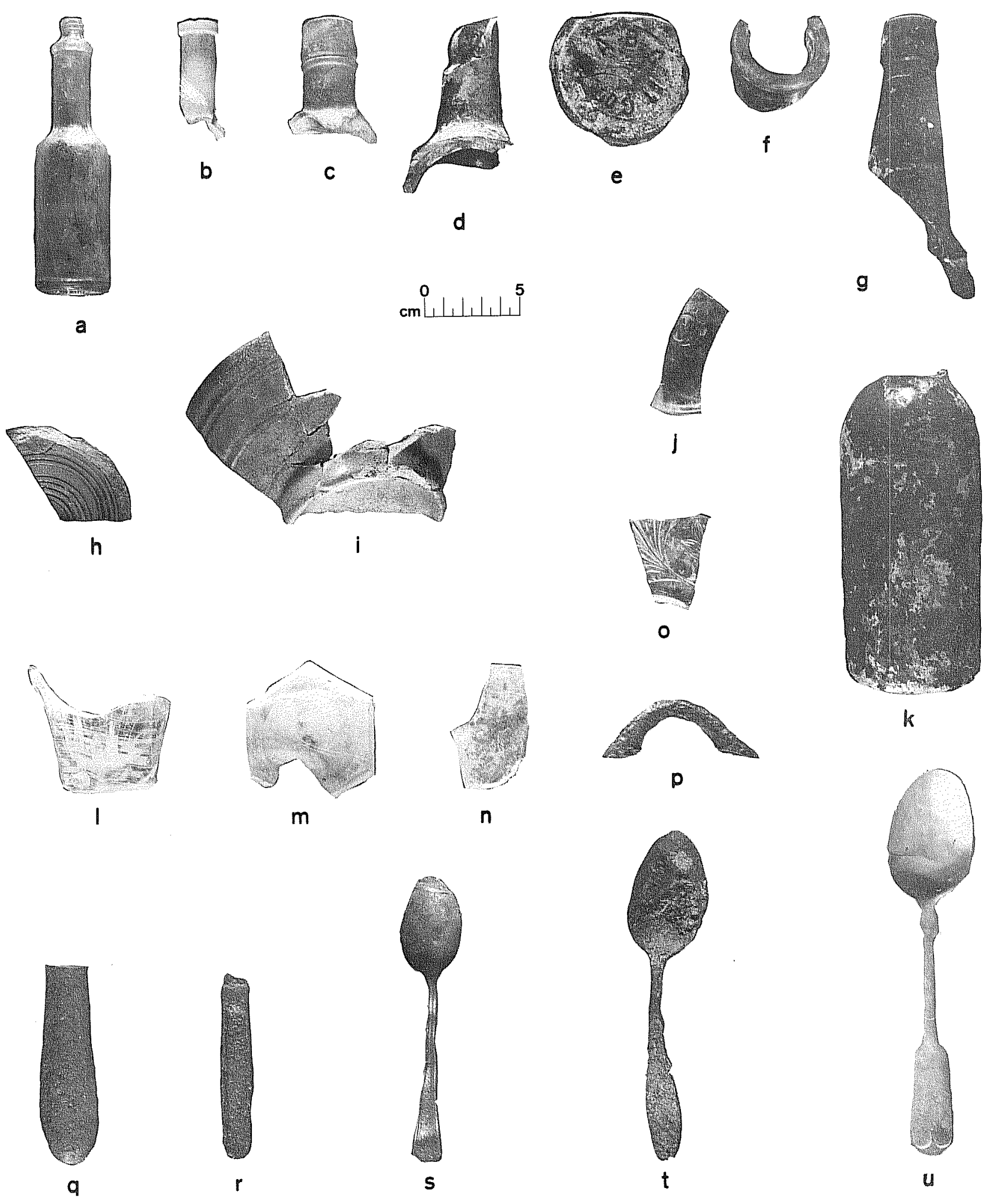




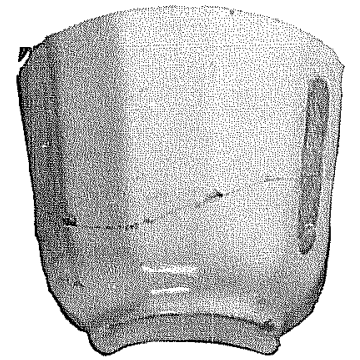

a
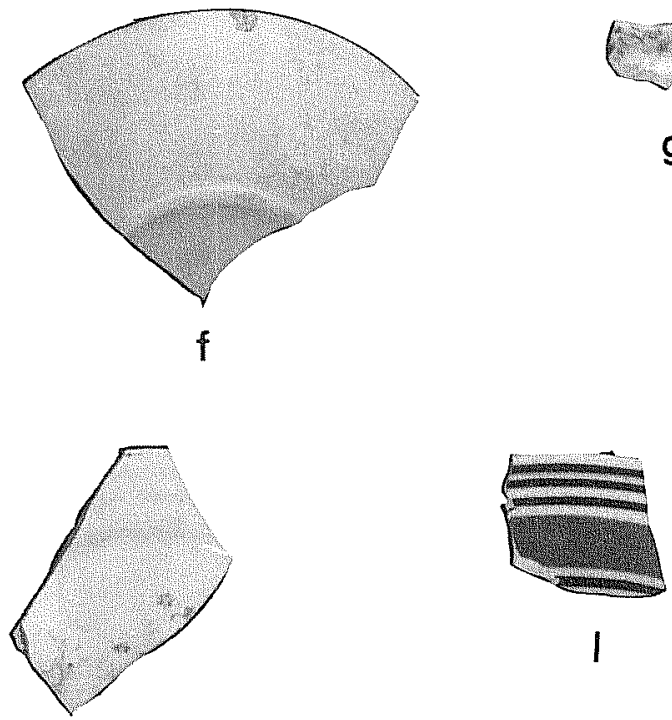

$k$

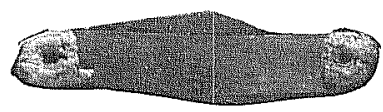

o

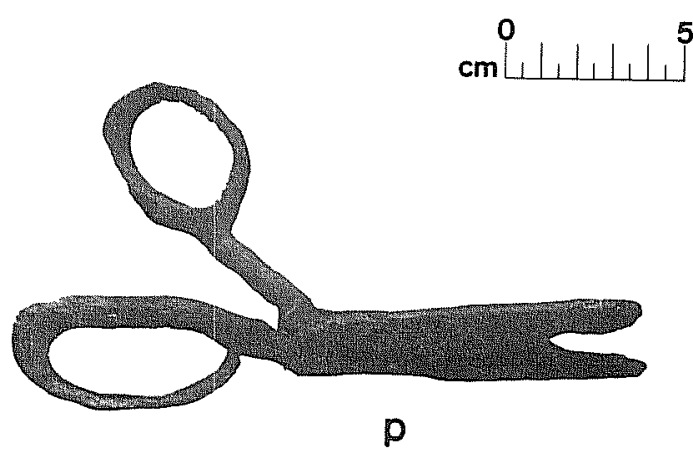

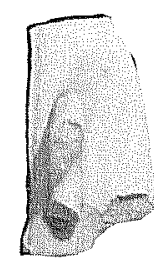

c

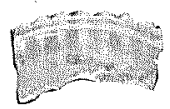

m

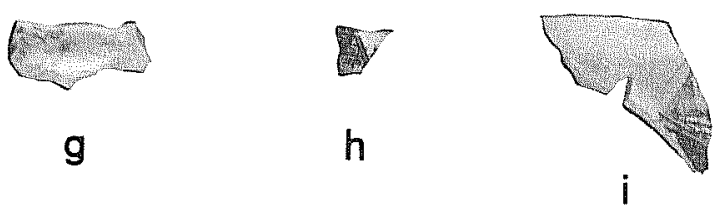

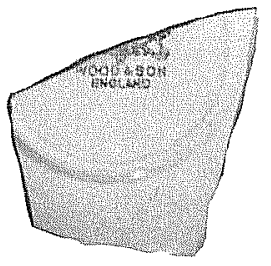

d

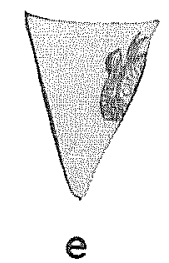

e
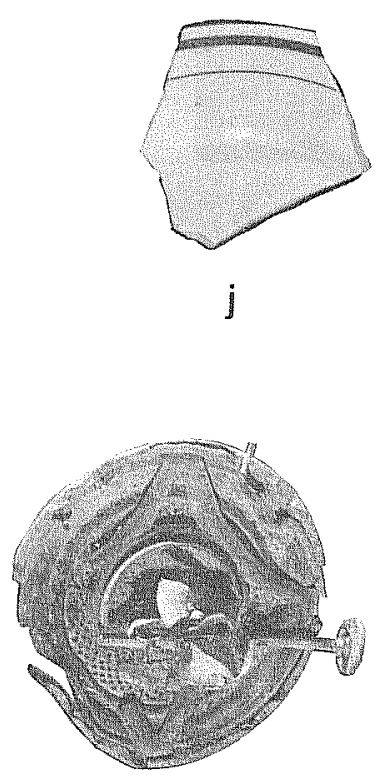

n

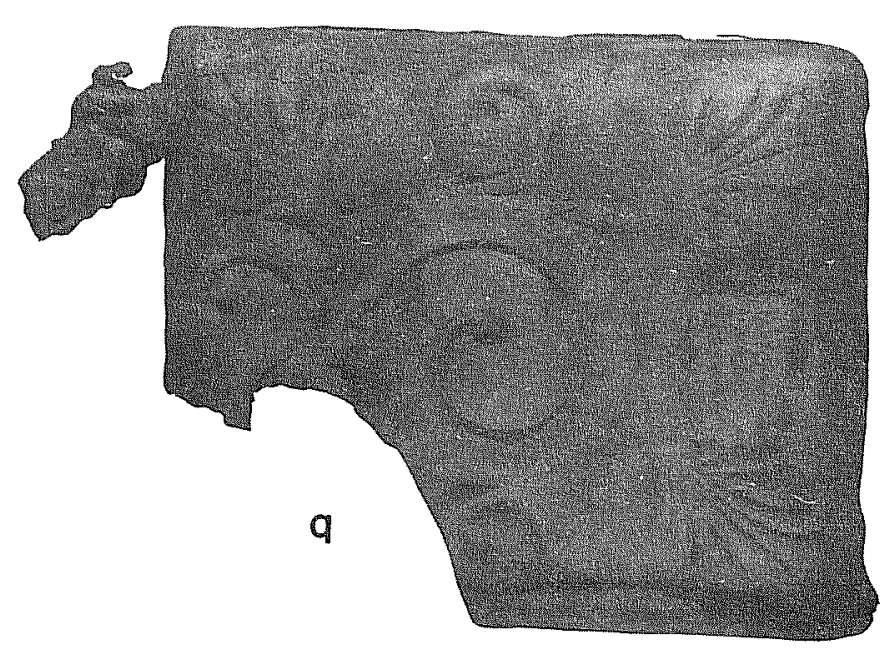

Figure 12. Food Serving Vessels, Housekeeping and Personal Articles. a-c, ironstone cups; d, ironstone plate with mark of Wood \& Son, England; e, ironstone plate with mark of Cartwright Brothers; $f$, ironstone saucer; $g$, decal rose design on porcelain; $h$, willow ware design on earthenware; $i$, semi-porcelain with decal design; $j$, semi-porcelain hotel ware; $k$, decal floral design on molded earthenware; 1, banded slipware bowl; m, lamp chimney fragment; $n$, oil lamp burner assembly; 0 , pocket knife; $p$, scissors; $q$, cast iron stove door. 
between 1891 and 1907 (Godden 1964:689). Ceramics of this sort were sold in stores in San Antonio throughout the last quarter of the 19th century and may well have been obtained there.

Other types of ceramics were also represented in the collection. of these, the only significantly early one consisted of two sherds of an English-made banded slipware bowl (Fig. 12,1). Although this type of ceramic ware was popular throughout Texas primarily in the 1840-1850 period, we have found that families tended to keep individual pieces in the household for years afterward, if they had a special use or sentimental value (see Fox and Livingston 1979:70).

Al so found among the ceramic sherds was white earthenware decorated with a transfer design in blue which was popularly called "Willow Ware" (Fig. 12,h). Since this design could be obtained throughout the 19th century and is still available today, it is impossible to date these sherds except in a very general way. The thickness of the sherds and the careless manner in which the design is executed suggest that they were inexpensive tablewares of the post-1900 period.

Post-1900 ceramics are also represented by a number of sherds of thin white and cream-colored wares with molded rim designs, some of which bear floral patterns applied with decalcomania. Such wares were readily available in local stores and mail-order houses throughout the 1900-1930 period.

One sherd of a heavy green-striped semi-porcelain plate (Fig. 12,j) probably came from a hotel or restaurant. Such wares are still in use today. Fragments of a heavy cup of the same material, with a decal design of a steamship (Fig. 12,i), were found on the surface near the stock pens.

The only pieces of fine china suggesting a woman's presence consisted of pieces of a cup and plate of thin white porcelain. The plate bears traces of a decal design of pink and yellow roses (Fig. 12,g,k). Such delicate dishes were popular in urban households around the turn of the century, but are a bit unexpected in a sheep ranch headquarters.

Three complete spoons (Fig. 11,s-u) were evidently discarded with the trash. A thin, silver-colored tablespoon of "plain tipped" design is stamped "Alaska" (Fig. 11,u). Sears, Roebuck and Company advertised "Alaska Silverware" in this pattern in their 1897 and 1902 catalogues (Israel 1968:438; Bounty Books 1969:99). A set of half a dozen tablespoons at that time cost \$1.02. Alaska Silverware was a cheap silver substitute invested by Sears about 1895. It was "the same solid metal through and through--very dense and tough--takes a beautiful polish and requires no care as does silver plated ware" (Israel 1968:438). In the 1927 catalogue this pattern was no longer available (Mirkin $1970: 760)$.

A teaspoon has the impressed mark "Saxon Silver Plate" (Fig. 11,s). The design is very similar to the patterns advertised in the 1927 Sears, Roebuck Catalogue (Mirkin 1970:754-758). Silver-plated teaspoons ranged from $\$ .80$ to $\$ 2.00$ for a set of six at that time.

A badly rusted and bent tablespoon may once have been silver plated (Fig. $11, t$ ). The sophisticated shape of the handle probably indicates that it was tableware 
rather than a cooking spoon. A fork handle with a depressed panel on either side (Fig. 11,r) is similar to the design of forks and knives issued by the Army around 1885 (Herskovitz 1978:65 and Fig. 24,a)

\section{Housekeeping}

Although the fireplace in the northernmost room appears to have been used for cooking, a plugged stovepipe hole noted in the chimney in one of the other rooms suggested that at least one stove was also in use in the house at some time. Therefore, it was not surprising to find numerous fragments of a cast iron cook stove in the trash disposal area behind the house. Of these pieces, three stove lids and a hinged door were recognizable (Fig. 12,q). The door bears a pattern of stylized leaves and curvilinear elements typical of ranges illustrated in the 1897 Sears Catalogue (Israel 1968:120-122). Such a stove could burn either wood or coal. Since no traces of cinders were found around the house, we can assume that the fuel used was wood, possibly cut on the ranch.

Another important housekeeping utensil was the copper wash boiler. The copper bottom is all that is left of a small boiler that measured ca. 10 inches by 18 inches and probably stood about 12 inches high. From the traces of rusted metal in the flanges around the rim, it seems that this wash boiler was made of tin, with copper only on the bottom. Such boilers sold for about $\$ .85$ each in the Montgomery Ward Catalogue of 1895 (Montgomery Ward and Co. 1969:434).

Early lighting in the ranch house is represented by the burner and wick assembly from a simple, oil lamp (Fig. 12,n). A fragment of a glass chimney used on this type of lamp was also found among the glass collection (Fig. 12,m).

\section{Personal Belongings}

As is often the case in late 19th-century sites, an interesting variety of personal effects were included among the artifacts. These include both personal belongings and objects such as one would pick up and save out of interest and curiosity.

In the category of personal items can be included a pocket knife (Fig. 12,0) and fragments of a cheap pocket watch (Fig. 13,a). Also personal in nature is a fragment of an unglazed red elbow pipe (Fig. 13,b) which would have had a detachable stem. The pipe is fluted and is stamped "ORIGINAL." Elbow pipes were popular throughout the 19th century and have been found in nearly every historic site investigation. Also, personal in nature is one lense from a pair of spectacles (Fig. 13,C). The 1897 Sears Catalogue (Israel 1968:28) had a complete Optical Goods department, from which one could test his eyes by reading various sizes of print and then order the proper strength of metalrimmed spectacles (with temples) or eye glasses (with nose pieces).

Collectors' items include a coastal shel1 (Fig. 13,d) and two fragments of worked stone probably picked up from a prehistoric camp site on the ranch (Fig. $13, e, f)$. The smaller piece is a gray chert tool made on a flake, showing considerable edge alteration and wear. The other is a crude biface made of red brown quartzitic stone. 
Leisure time activities are represented by a molded, barrel-shaped lead fishing weight and four marbles (Fig. 13,g-i). Of the latter, two are of clay and two of glass. Clay marbles were popular during the last part of the 19th century and sti11 available up to the end of World War I (Randa11 1971:103). Although glass marbles have been made since the 15th century (ibid.:104) these appear to be machine made, which would date them after 1900.

Two contemporary coins (Fig. $13, j$ ) were also found on the site. These are identical Venezuelan one bolivar coins minted in 1967. Perhaps the Harrison family can account for the origin of these.

Other activities which were pursued on the site would have required the use of scissors. Two pair of these were found, one of which is complete (Fig. 12,p). A fragment of a glazed stoneware ink bottle is typical of those produced by J. Bourne and Son of the Derby Pottery for the Arnold Ink Company of London (Fig. 13,k). This is another artifact common on historic sites. The stoneware bottle would have been the master ink storage container from which a smaller glass ink bottle would have been filled for everyday use. Such a bottle is represented by a portion of an octagonal, umbrella-shaped aqua glass container (Fig. 13, 1).

Another aspect of personal life on the ranch was the treatment of illnesses of various kinds. Bottles identifiable as medicines were proportionally fewer than often found on late 19th-century sites. There is a group of clear and aqua-colored necks from panel type medicine bottles (Fig. 13,q-s) such as were dispensed by a druggist in the 1880s. A small brown cylindrical bottle (Fig. $13, w)$ could have held medicine for man or livestock. A whole aqua bottle (Fig. 13,x) bears the embossed 1abel, "Dr. G. F. BROWN'S/ YOUNG/AMERICAN/ LINIMENT/NEW YORK." Its use is self-evident. More recent bottles include

familiar labels: 'Milk of Magnesia, Vicks Vaporub, and Mentholatum (Fig. 13,v).

A bottle shaped like those for hair tonic (Fig. 13,u) is labelled, "FouR ROSES/QUATRO ROSAS," indicating the product may have originated in the border area. Finally, the only artifact from the collection that strongly suggests a feminine presence is a milk glass jar bearing the label, "NADINOLA CREAM/ A COMPLEXION BEAUTIFIER/NATURAL TOILET C0./PARIS ---" (Fig. $13, t$ ).

\section{Clothing}

Three metal fasteners in the collection are of interest. One is the facial portion of an undecorated compound button (Fig. 13,0). Another resembles a shirt or collar stud, and appears to be a "Hand Snap" two-part button such as were widely sold in the 1890s ( $F i g .13, n$ ). "By the use of these buttons the traveling man, the farmer, the laborer, the mechanic, the growing boy and his father, of any profession, can instantly replace his missing buttons" (Israel 1968:320). The third fastener is a two-piece gripper made to snap onto a base having a bulbous projection. Engraved on the back are the letters "U.S.F.CO." probably the manufacturer (Fig. $13, p$ ).

Fragments of shoe leather appear to represent a boot or shoe from the earliest occupation of the house. The sole is machine-nailed to the upper, and no 
Figure 13. Personal Articles, Medicine, Clothing, and Harness Bridles.

a, pocket watch;

b, red clay elbow pipe fragment;

c, spectacle lense;

d, coastal shell;

e, biface, quartzitic stone;

$f$, chert tool;

$g$, lead fishing weight;

$h$, clay marbles;

$i$, glass marbles;

$j$, Venezuelan one bolivar coin, 1967;

$k$, stoneware ink bottle;

1 , glass ink bottle;

$m$, brass shoe scuff plate;

$n$, two-piece metal button;

0 , face of compound button;

$p$, metal gripper;

$q$, medicine bottle neck, clear;

$r$, medicine bottle neck, aqua;

$s$, medicine bottle neck, aqua;

$t$, milk glass container;

$u$, hair tonic bottle;

$v$, milk glass ointment jar;

$w$, brown medicine bottle;

$x$, aqua liniment bottle;

$y$, harness buckle, iron;

$z$, harness buckle, iron;

aa, harness buckle fragment, iron;

bb, harness buckle, brass. 


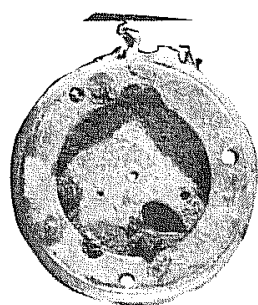

a

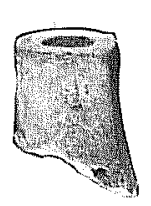

b

(2)

g

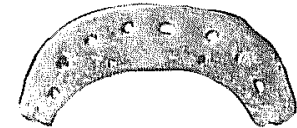

m

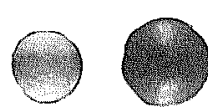

h n
C
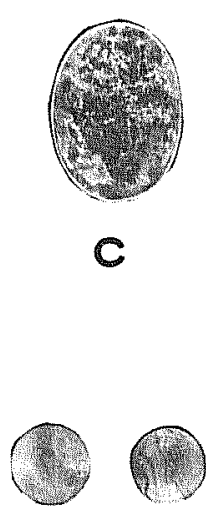

i

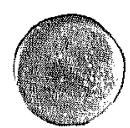

0
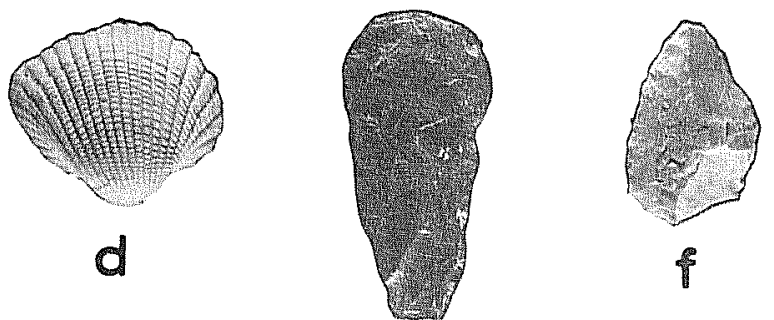

e

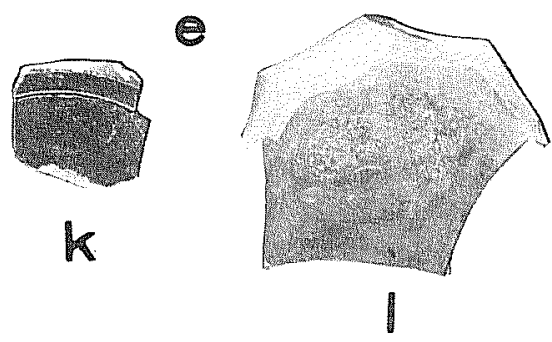

1

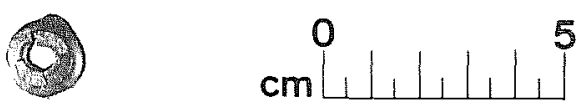

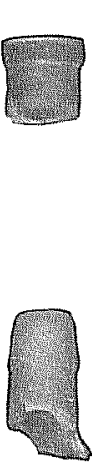

r

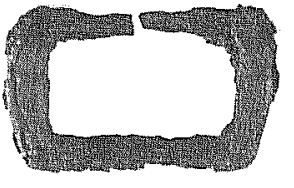

y

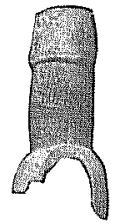

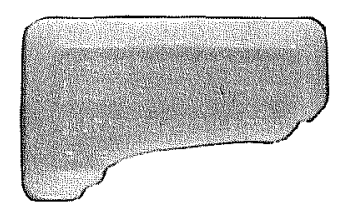

t

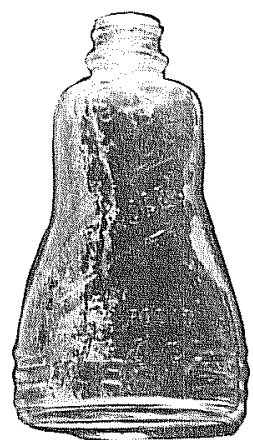

u

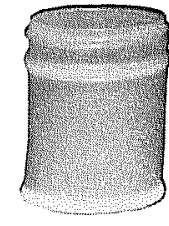

V

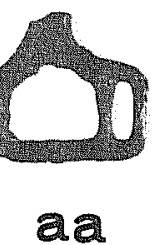

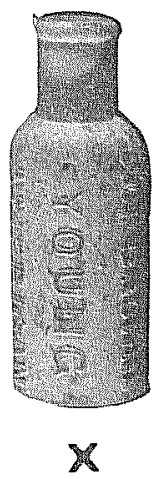

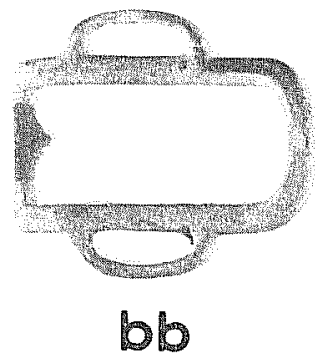


stitching was used in the process. This dates its manufacture to post-1862 and probably before 1890 (Anderson 1968:59-61). Also of interest was a brass scuff-plate from a child's shoe (Fig. 13, m). These plates were installed on the toes of children's shoes during the period just after the Civil War (Smith 1976:208). The plate was nailed onto the toe by inserting a flange between the sole and the upper before nailing them together. Two identical plates were found during CAR excavations in downtown Laredo in 1980 (Folan et al. 1982).

\section{Ranching Equipment}

A large collection of heavy metal objects connected with the ranching operation was also found in the trash disposal area. Since these do not apply directly to the occupation and construction of the house, we will describe these briefly, illustrating only those of particular interest. As in most late 19th-century farm and ranch collections, there are many broken fragments of machinery which are virtually unidentifiable except by one who has worked with the piece of equipment involved. Of these, we have chosen the more recognizable pieces for discussion.

\section{Tools}

The usual tools found "around the place" at most such establishments were found here. The heads for a large, single-bitted axe, a small hatchet (Fig. 14,i), and a mattock are included in the collection. Also present are a 12-inch bastard file and a broken chisel (Fig. 14,j). A less commonly found implement is a branding iron (Fig. 14,n).

\section{Machinery}

The most essential piece of machinery to this day on many south Texas ranches is the windmill. Two slightly different sucker rod attachments were found on the site, one of which bears the label "COL.S.S.R. CO." Also having to do with the water supply is the top to an old fashioned pitcher spout pump.

Several sickles from a mowing machine (Fig. 14,k) are among the artifacts. Of more recent vintage are a machinery pressure gauge and an Autolite spark plug.

Horse and Wagon Hardware

An axle clip, a singletree center clip, a tug clip, and an eyed bolt (Fig. 14,d-g) are all part of harness and wagon hardware. A number of different types of buckles and other fasteners (Fig. 13,y-bb) were also in the collection, along with a heavy chain link $(14, c)$.

An iron pommel from a saddle (Fig. 14,0), a pierced iron stirrup (Fig. 14,1), and two fragments of bridle bits ( $F i g .14, a, b)$ represent the equipment necessary for a late 19th-century vaquero. A mule shoe (Fig. 14,m) probably represents the freight wagons which stopped at the ranch, and a broken horseshoe rounds out the collection. 

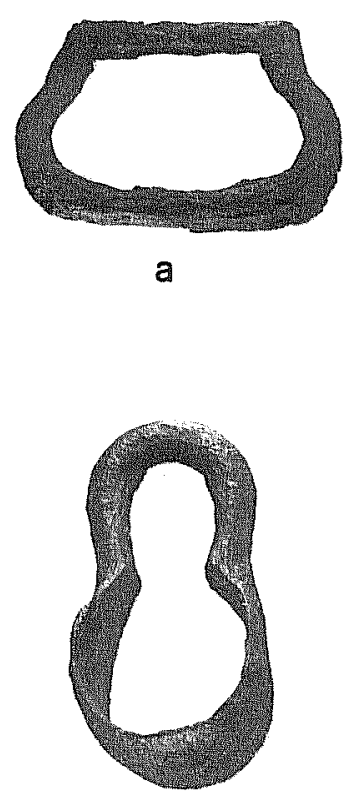

e

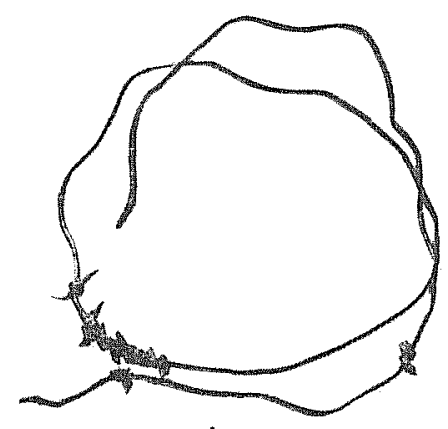

h

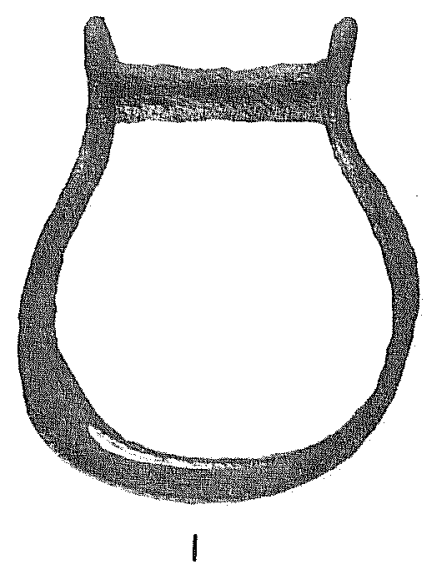

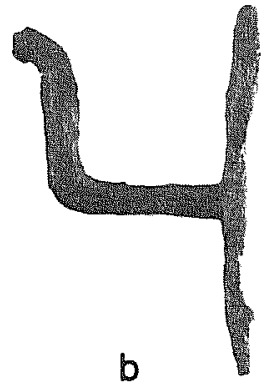

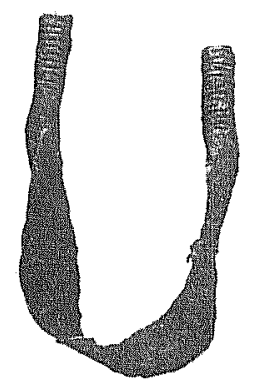

f

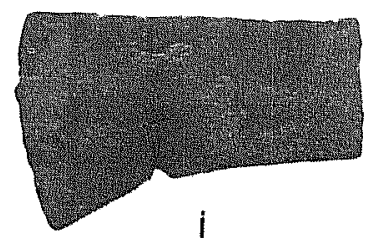

m

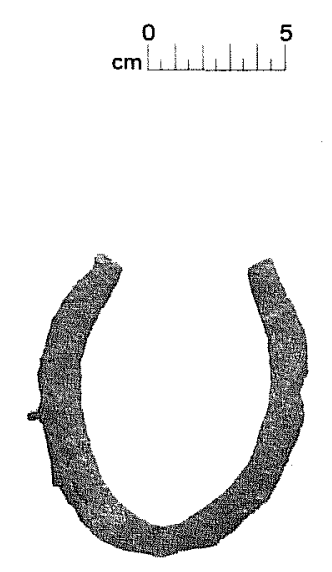

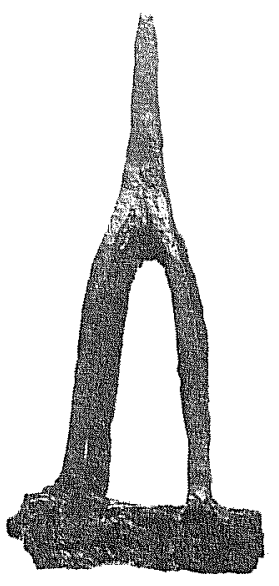

n
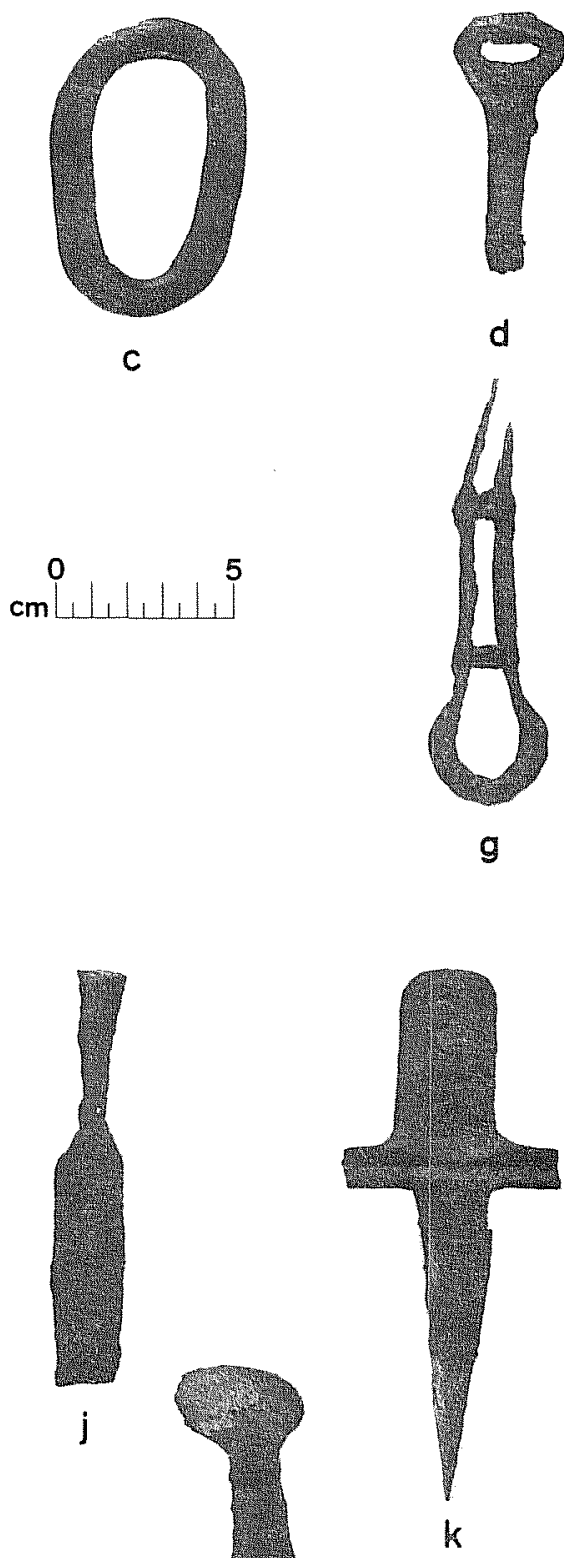

o

Figure 14. Horse, Wagon, and Ranching Hardware. a, "D" ring from saddle rigging; b, broken ring bit; $c$, heavy chain 1ink; $d$, eyed bolt; e, singletree center slip; $f$, axle clip; g, tug clip; $h$, early barbed wire; $i$, small hatchet head; $j$, chisel; $k$, mowing machine sickle; 1, pierced iron stirrup; m, mule shoe; $n$, branding iron, simple " $x$ "; 0 , iron saddle pommel. 


\section{DISCUSSION}

Careful examination of the artifacts found during the recent restoration work at the Valenzuela Ranch has yielded some interesting details about the house and its various residents over the years. Although the materials represent the entire range of occupation from the founding of the ranch as a sheep-raising operation in the 1870 s to its use in recent years as a hunting camp, the bulk of the material represents the 1870 to 1900 period. This corresponds to the sheep-ranching operation; during which time James Carr's nephew, Daniel French, resided there (WCPR 1896a File No. 285:Daniel French). As might be expected, the overall picture is of a bachelor establishment with few, if any, indications of a woman's touch.

In order to correctly interpret the artifacts found at the house, some understanding of sheep ranching and the life of the people connected with it will be of interest. A number of excellent books and articles have been written on sheep raising in Texas. Perhaps the most pertinent to this discussion are Forgotten Legions (Lehmann 1969) and Letters from a Texas Sheep Ranch (Brown 1959) which contain actual letters from people living under the same circumstances. From these and other sources we can recreate the following picture of life on a south Texas sheep ranch.

In the late 1870s, when Kearney and Carr began their partnership in the sheepraising business, sheep and cattle roamed freely in south Texas, and fences were used primarily to keep the livestock out of the rancher's garden, or for controlling livestock for specific purposes in the vicinity of the ranch headquarters. In some cases, sheep owners obtained permission to use pastureland in exchange for paying the tax on it (Sweet and Knox 1883:466). Sheep raising was very profitable, and the number of sheep grazing in Texas in 1879 was estimated at 15 million, with 700,000 in Nueces County alone (ibid.). By 1882, Dimmit County had about 12 times as many sheep and goats as cattle (Lehmann 1969:30).

Starting in the sheep business required capital to establish the flock (Lehmann 1969:36) and land for a headquarters out of which to operate. It appears that the Valenzuela stone house was constructed about the time the partnership between Kearney and Carr began. It could even be that Kearney built the northern two rooms before Carr joined him, and the other rooms were added later as needed. The location of defensive loopholes only in the first two rooms on the north certainly suggests this portion was built during the time of most immediate danger from Indians and bandits. According to local history, the last Indian fight in the county occurred in 1876 (Wi11iams 1979c:11). The plague of Mexican bandits who raided south Texas calmed down about 1878 (Cook n.d.:27).

There was a strict tradition about the organization of a south Texas sheep ranch operation. This appears to have originated in Mexico, the country from which most of the workers came. The pastor, with his dog, spent all of his time with a flock of about 2000 sheep. He carried his beans, coffee, and bedroll with him on a burro (Brown 1959:56), and pitched camp in a different spot every night as the sheep grazed across the countryside. His shelter was a crude tent or brush pile (Lehmann 1969:37). A smal1 herd of goats provided 
meat for the pastores to go along with their supper of beans, tortillas, and coffee (Carison 1982:57).

Overseeing three pastores with their 6000 sheep was a vaquero, who supervised the care of three flocks. Next in line was the caporal who supervised three vaqueros and about 18,000 sheep. He provided monthly reports and personally supervised the apportionment of provisions to the camps from the ranch headquarters. Above the caporal was the mayordomo, an experienced sheepman, who kept a constant watch on the camps and recommended range usage and movement of the flocks (Carlson 1982:56-57; Lehmann 1969:49-50; Brown 1959:56).

The ranch foreman supervised the entire operation and made major policy decisions, in the absence or with the consent of the owner. As was apparentiy the case on the Valenzuela Ranch, the owner lived in town and depended on his foreman to run the ranch.

According to the 1880 agricultural census (USDI 1880), James Carr had 28,000 sheep and 80,000 new 1 ambs as of June 1, 1880. This implies a staff of 18 pastores, six vaqueros, two caporales, and a mayordomo plus the foreman. of these, the vaqueros, caporales, and mayordomo would probably have lived close to the headquarters. The stone house would not have been large enough for a bunkhouse sort of arrangement, and was probably the foreman's quarters, with room for the owners when they visited the ranch. Small frame shacks in the immediate vicinity would have housed the other men and their families when they were with them. This would explain the small house site we found on the top of the hill overlooking the stone house during our survey. There were probably other, similar small house sites in the vicinity.

A rather surprising amount of other livestock was also listed in Carr's census inventory, including 175 horses, 25 mules, 20 working oxen, $120 \mathrm{milk}$ cows, and 260 other cattle. There were also 500 swine and 40 barnyard poultry. It appears that all of this operation was taking place on the Valenzuela Ranch, along with the sheep-raising activities. Evidently this combination of sheep and other 1ivestock was not unusual, as Brown (1959:56) mentions "stock" on a sheep ranch which included horses, cattle, and mules, as well as work oxen, (ibid.:61-62) and milk cows (Brown 1959:85).

While the sheep spent most of the year on the pastures, periodically they were returned to the headquarters for specific purposes. Twice a year in south Texas (Carlson 1982:77) a Mexican shearing crew arrived to shear the flocks. Fleeces were tallied, tied, and sacked, then freighted to the nearest wool market. At the same time wounds were treated, and marking, castrating, and docking were done (ibid.:59).

Sheep were subject to a number of diseases, which necessitated periodic dipping. At first when the industry was starting and flocks were comparatively small, sheep were dipped individually in the large cast iron pots also used to mix the dip (Lehmann 1969:101). Later large vats were bui1t, such as the one on the Valenzuela Ranch (Fig. 4) through which a steady stream of sheep could be run in a large-scale operation.

Judging from the above description, one can see that the headquarters was the nerve center and base of a large and complex operation. The number of people 
there would have varied, depending on the season, from a handful to 50 or more. Between the times of frantic activity stretched lonely periods during which letters written to loved ones far away reflected the feelings of the foreman:

- . but once since my return to the ranch have I seen anyone -- who spoke my own language. The monotony of 1 ife is rarely disturbed. --- I usually, after eating breakfast, spend one or two hours in the saddle riding, looking at the stock, talking to the men, and listening to what they have to say of their work or troubles or disputes --- and in this way dinner time comes and I sit down to such cheer as a poor cook and still poorer larder affords. --- I am writing by the light of a lantern with a wick made of an old felt hat and it gives a miserable light (Lehmann 1969:161).

Looking again at the artifacts, we can see a confirmation of all this in the heavy ironstone dishes, the crude cooking utensils, the ink bottles, and lamp parts. The comparatively sparse collection of food containers among the glass collection, not to mention the medicine and whiskey bottles, could be said to reflect a rather uninspired cook and a predominantly masculine population.

\section{REFERENCES CITED}

Anderson, A.

1968 The Archaeology of Mass-Produced Footware. Historical Archaeology II:56-65.

Anonymous

1907 Twentieth Century History of Texas. Vol. I. Lewis Publishing Company, Chicago, Illinois.

Bexar County, Texas

Bexar County Deed Records (BCDR)

Originals and microfilm in Bexar County Courthouse, San Antonio, Texas.

Bexar County Probate Records (BCPR)

1945 File No. 57299: Last Will and Testament of Wilhelmina Kotula, dated March 24, 1922; filed December 14, 1945. Originals in Bexar County Courthouse, San Antonio, Texas.

Bounty Books

19691902 Edition of the Sears, Roebuck Catalogue. Crown Publishers, Inc., New York. 
Brown, H. J., editor

1959 Letters from a Texas Sheep Ranch. University of I17inois Press, Urbana.

Carlson, P. H.

1982 Texas Woollybacks, The Range Sheep and Goat Industry. Texas A\&M University Press, College Station.

Cook, F. S.

n.d. Dimmit County Almanac and Guide. P \& H Publishing Company, Amari110, Texas.

Dimmit County, Texas

Dimmit County Deed Records (DCDR)

Originals in Dimmit County Courthouse, Carrizo Springs, Texas.

Dimmit County Probate Records (DCPR)

Originals in Dimmit County Courthouse, Carrizo Springs, Texas.

Folan, W. J., I. W. Cox, A. A. Fox, and G. M. Hinojosa

1982 Laredo, Texas: A Gateway Community on the Texas Borderlands. Archaeological and Historical Investigations for the Laredo

City Toll Plaza. Center for Archaeological Research, The University of Texas at San Antonio, Archaeological Survey Report 116 (in preparation).

Fontana, B. L. and J. C. Greenleaf

1962 Johnny Ward's Ranch: A Study in Historic Archaeology. The Kiva $28(1-2)$.

Fox, A. A.

1978 Excavations of Features 4 and 4W. In Archaeological and Historical Investigations in the Arciniega Street Area, Downtown San Antonio, Texas, by Paul Katz:41-72. Center for Archaeological Research, The University of Texas at San Antonio, Archaeological Survey Report 61.

1982 The Valenzuella Site, An Archaeological Assessment. Manuscript on file, Center for Archaeological Research, The University of Texas at San Antonio. 
Fox, A. A. and K. Livingston

1979 Architectural and Archaeological Investigations at the SteinerSchob Complex, Coleto Creek, Victoria, Texas. Center for Archaeological Research. The University of Texas at San Antonio, Archaeological Survey Report 52.

George, $E$.

1975 Historic Architecture of Texas, The Falcon Reservair. Texas Historical Foundation, Austin.

Godden, G. A.

1964 Encyclopaedia of British Pottery and Porcelain Marks. Bonanza Books, New York.

Government Land Office (GLO)

1887 File No. 1-554, Survey 2182, Ju1y 8, 1887. Austin Building, Austin, Texas.

1872, File No. S-1565, Survey 413, June 12, 1872, July 10, 1875.

1875 Austin Building, Austin, Texas.

Herskovitz, R. M.

1978 Fort Bowie, Material culture. The University of Arizona Press, Tucson.

Israel, F. L., editor

19681897 Edition of The Sears, Roebuck Catalogue. Chelsea House, New York.

Johnson, F. W.

1914 A History of Texas and Texans. American Historical Society, Chicago, I11inois.

Lehmann, V.W.

1969 Forgotten Legions, Sheep in the Rio Grande Plain of Texas.

Texas Western Press, El Paso, Texas.

Mings, S. D.

1976 The Valenzuella Site: Settlement on the Ranching Frontier in South Texas. Privately printed, Austin, Texas. 
Mirkin, A., editor

19701927 Edition of The Sears, Roebuck Catalogue. Crown Publishers, Inc., New York.

Montgomery Ward and Co.

1969 Catalogue No. 57, Spring \& Summer, 1895. Dover Publications, Inc., New York.

Morrison \& Fourmy

1881-1882 General Directory of the City of San Antonio.

Randa11, M. E.

1971 Early Marbles. Historical Archaeology 5:102-105.

Raycraft, D. and C. Raycraft

1975 American Country Pottery. Wallace-Homestead Book Co., Des Moines, Iowa.

Schuetz, M. K.

1970 Excavation of a Section of the Acequia Madre in Bexar County Texas, and Archeological Investigations at Mission San Jose in Apri1, 1968. Texas Historical Survey Committee, Archeological Report 19.

Smith, S. D.

1976 An Archaeological and Historical Assessment of the First Hermitage. Tennessee Department of Conservation, Research Series 2. Nashville, Tennessee.

Sweet, A. E. and J. A. Knox

1883 On a Mexican Mustang Through Texas. S. S. Scranton Co., Hartford, Conn.

Thorn, C. J.

1947 Handbook of Oed Pottery and Porcelain Marks. Tudor Publishing Company, New York.

Toulouse, J. H.

1971 Bottle Makers and Their Marks. Thomas Ne1son, Inc., New York. 
United States Department of the Interior, Office of the Census (USDI)

1880 The Tenth Census, 1880. Returns of Schedule One, Population. Webb County, Texas, July 13, 1880. Returns of Schedule Two, Agriculture. Webb County, Texas, June 11, 1880.

Webb County, Texas

Webb County Deed Records (WCDR)

Originals in Webb County Courthouse, Laredo, Texas.

Webb County Probate Records (WCPR)

1896a File No. 285: Last Will and Testament of Thomas Kearney, June 4, 1896, Deposition of Emma Schmidt, Deposition of Daniel French. Webb County Courthouse Annex, Laredo, Texas.

1896b File No. 556: Last Will and Testament of Blasa Carr, June 3, 1896. Webb County Courthouse Annex, Laredo, Texas.

Wilkinson, J. B.

1975 Laredo and the Rio Grande Frontier. Jenkins Publishing Company, Austin, Texas.

Williams, C. S.

1979a A History of Dimmit County. The Carrizo Springs Javelin. Carrizo Springs, Dimmit County, Texas, March 22, 1979.

1979b A History of Dimmit County. The Carrizo Springs Javelin. Carrizo Springs, Dimmit County, Texas, March 8, 1979.

1979c A History of Dimmit County. The Carrizo Springs Javelin. Carrizo Springs, Dimmit County, Texas, Apri1 12, 1979. 


\section{APPENDIX I}

\section{BIOGRAPHIES}

\section{Dr. Thomas Kearney}

Dr. Kearney was born on Staten Island, New York, on September 4, 1810. In 1837, he married Mrs. Elizabeth Hicks Caldwel1 in Clinton, Mississippi (WCPR 1896a File No. 285:Constance K. Vertner). Mrs. Caldwel1 was at that time the wealthy widow of Judge Isaac Caldwell (ibid.: Edmund Kearney). She had two daughters and a son from her first marriage, all of whom grew to maturity. With Kearney she had a son, Edmund, born in 1838, and a daughter, Constance, born in 1841. The son, a captain in the Confederate States Army, married in 1865 and was widowed in 1870. He married again in 1888, and resided in Jefferson County, Mississippi. The daughter, Constance, married a Mr. Vertner of Luray, Virginia. They had three children (WCPR 1896a File No. 285:Edmund Kearney).

Little could be found about Kearney's whereabouts from the 1840s to the 1860s. His wife died in 1842, leaving a generous estate to her children. Apparently, Kearney managed his children's share of the estate, which amounted to $\$ 30,000$ (ibid.), from which he apparently bought numerous pieces of real estate. Possibly a portion of this money helped finance his purchase of Dimmit County land in the 1870s and 1880s.

In 1862, Dr. Kearney was in Monterey, Mexico (WCPR 1896a File No. 285:U1rich), perhaps because his Union sympathies made it impossible to remain in the South. In 1869, after an epidemic of yellow fever in Nueces County, he accepted the position of Quarantine Officer at the Port of Corpus Christi and retained the position until August of that year (Nueces County Historical Society 1972:134). The following year he was the Collector of Customs at the Port (USDI 1870:

Nueces County). Also during that year he was active in politics in support of President Grant (Nueces County Historical Society 1972:81).

Two years later, in 1872, Kearney purchased his first piece of 1and in Dimmit County, the one on which the stone house is built. Three years after that he was in partnership with James $A$. Carr of Laredo, acquiring additional 1 and in the area (DCDR 1875 Vol. 6:137 et seq.). It seems 1ikely that Kearney and Carr had become acquainted on the border during the Civil War.

Soon after Carr and Kearney began acquiring land in common, Kearney turned up in San Antonio, where he built a home and acquired other properties. He lived in San Antonio for the rest of his life, making frequent trips to visit his children in Mississippi and to the Carr home in Laredo, as well as to his various ranching interests.

Dr. Kearney died in a "lodging house" in San Antonio (of which he was the owner) in 1896, and was buried in the Catholic cemetery, in a "marble vault built by him years before" (WCPR 1896a File No. 285:Schasse). He had become increasingly $i 11$ and senile during his last years, and made numerous wills before he died, leaving an estate valued at $\$ 125,000$. His family contested his 
final will, which resulted in a large file of depositions, now stored in the Webb County Courthouse (WCPR 1896a File No. 285). It was these depositions which made it possible to reconstruct Dr. Kearney's life story in such detail. They also have provided a number of important facts about the operation of the Valenzuela Ranch and the life of James Carr, which we would not otherwise have known.

James A. Carr

Census reports differ on the date and location of Carr's birth. The 1870 census states that he was 38 years old and was born in Massachusetts, whereas the 1880 census has him 51 years old at that time and coming from Alabama.

In 1870, Carr and his wife, Blasa, were residing in Laredo. His occupation was listed as "Military Guide" (USDI 1870:Webb County). James and Blasa had no living children at that time. They adopted and/or raised several children over the years, all probably related to them in some way: Daniel French, Carr's nephew (born in 1865); Santiago Guajardo, commonly known as Santiago A. Carr (1874-1909); Blasa Charo (born in 1896); and Euleteria Carr, born in 1899 and living with them from the age of one year (WCPR 1896b File No. 556:Blasa Carr; USDI 1870: Webb County).

Carr went into the sheep-ranching business with Dr. Kearney in 1875 or 1876 in Dimmit County. It appears that Dr. Kearney's primary interest was in the financial investment, and that he left the livestock management to Carr. The 1880 Agricultural Census (USDI 1880: Webb County) 1ists the following information about Carr's holdings:

Value of farm, including buildings and fences

Fences, cost of building and repairing in 1879

$\$ 25,000$

Labor, paid for during 1879

$\$ 500$

Estimated value of all farm production

$\$ 2,000$

Acreage, grass not mown

$\$ 16,240$

Horses, of a11 ages

8,000

Mules

175

Meat cattle

working oxen

milk cows

other

slaughtered

butter made

720 lbs.

Sheep

28,000

Lambs dropped

8,000

Sold living

8,116 
Slaughtered

1,000

Clip, Spring 1880, shorn or to be shorn

24,500 fleeces

Swine

500

Pouttry, Barnyard

40

Carr continued in ranching until 1894, when he sold the Valenzuela Ranch to Edward Kotula. He died soon thereafter, leaving all of his estate to his wife (WCPR 1896b File No. 556:Blasa Carr).

Edward Kotula

Ed Kotula was a prominent San Antonio merchant, dealing in commodities, primarily wool. He earned the title "Wool King of Texas." He was born in Poland in 1844, the son of Carl and Elizabeth Kotula. The family immigrated to the Polish community of Panna Maria in 1854. His father died the following year, and he and his mother moved to San Antonio. She resided there until her death in 1906 at the age of 93. He received his education at 01d St. Mary's College and during the Civil War was employed as a mail carrier between San Antonio and Boerne, and, later, Victoria (Johnson 1914:1257).

After the war he was employed as a clerk with the firm of D. \& A. Oppenheimer, dealing in wholesale dry goods, wool, and cotton (Engelhardt 1891:73). In 1869, he opened a grocery store in an old adobe building on the corner of Alamo and Commerce Streets, where the present Joske's Building is 1ocated. In 1871, he constructed a two-story building across the street, and later relocated his business to the south side of Military Plaza. Until 1893 he remained one of San Antonio's most successful merchants, transacting over a half million dollars a year in wool commissions.

Subsequent to his purchase of the Valenzuela Ranch in 1894, he listed his business as real estate, and he took pride in his herds of Durham and Hereford cattle (Johnson 1914:1238). In 1907, the ranch was reported to consist of 43,000 acres, indicating that it was still intact as sold by Carr.

Kotula was married to Wilhelmina Steng, whose parents came from Germany in 1845. They had five children (BCPR 1945 File No. 57299:Kotula). He died in 1907 in San Antonio, while preparing for a visit to the ranch.

His sudden death yesterday, coming in the midst of apparent good health and vigor, brings both surprise and grief to his host of friends and acquaintances (The San Antonio Daily Express 1907).

\section{Thomas Lewis Latané Temple}

Temple, a lumberman and industrialist, was born March 18, 1859, in Virginia. He was orphaned at 11, and migrated to Arkansas at 17 years of age. He moved to Texarkana in 1877, and went into the lumber business. In 1893, he purchased 7000 acres of timber in Angelina County, Texas, and opened his first sawmill. 
He rapidly rose in prominence, and at his death in 1935, had an interest in over a dozen operations (Branda 1976:961).

References Cited

Bexar County, Texas

Bexar County Probate Records (BCPR)

1945 File No. 57299: Last will and Testament of Wilhelmina Kotula, dated March 24, 1922; filed December 14, 1945. Originals in Bexar County Courthouse, San Antonio, Texas.

Branda, E. S., editor

1976 The Handbook of Texas, A Supplement. Vo1. 3. Texas State Historical Association, Austin, Texas.

Dimmit County, Texas

Dimmit County Deed Records (DCDR)

Originals in Dimmit County Courthouse, Carrizo Springs, Texas.

Engelhardt, G. W.

1891 The Engelhardt Series. American Cities, San Antonio Texas. Reprinted by Norman Brock, San Antonio, Texas, 1977.

Johnson, F. W.

1914 A History of Texas and Texans. American Historical Society, Chicago, Illinois.

Nueces County Historical Society

1972 The History of Nueces County. Jenkins Press, Austin.

The San Antonio Daily Express

1907 Prominent Man Suddenly Expires at His Home Here. Sunday Morning, May 12, 1907.

United States Department of the Interior, Office of the Census (USDI)

1870 The Ninth Census, 1870. Returns of Schedule One, Population. Webb County, Texas, August 23, 1870.

1880 The Tenth Census, 1880. Returns of Schedule One, Population. Webb County, Texas, July 13, 1880. Returns of Schedule Two, Agriculture. Webb County, Texas, June 11, 1980. 
Webb County, Texas

$1896 a$ Webb county Probate Records (WCPR)

File No. 285: Deposition of Constance K. Vertner, Deposition of Edmund Kearney, Deposition of J. UTrich, Deposition of Schasse, Last Wi11 and Testament of Thomas Kearney, June 4, 1896. Webb County Courthouse Annex, Laredo, Texas.

1896b File No. 556: Last Will and Testament of Blasa Carr, June 3, 1896. Webb County Courthouse Annex, Laredo, Texas. 


\author{
APPENDIX II \\ NOTES ON PREHISTORIC ARCHAEOLOGY AT PILONCILLO RANCH, \\ SOUTHERN TEXAS
}

Thomas R. Hester

During a visit to the headquarters of the Piloncillo Ranch in October 1982, the author was shown a number of prehistoric Indian artifacts collected over the years from various sites on the Piloncillo and adjacent Valenzuela Ranches. In this appendix to the historic archaeological study conducted by Fox and her colleagues, some notes are provided on these artifacts. Previous archaeological studies of the ancient hunting and gathering Indian populations in the Dimmit County area have been published by Nunley and Hester (1966) and Hester (1980). The survey activities of Nunley and Hester (1966:241-243) led to the documentation of four prehistoric sites on the Piloncillo Ranch. These sites were designated as 41 DM 22, 41 DM 23, 41 DM 24, 41 DM 25, and 41 DM 26. A11 the sites yielded surface finds of Middle and Late Archaic projectile points; at 41 DM 22, Late Prehistoric arrow points were found.

\title{
Paleo-Indian Artifacts
}

At least two projectile points in the collection date from the Paleo-Indian period, the earliest known occupation in the region. One specimen is a Golondrina point (Fig. 15,a), which probably dates to around 7000 B.C. (Hester 1980). Another is an Angostura point, made of heat-treated flint. Such intentional heating of the stone was done to improve its chipping qualities. This point probably dates around 6000 B.C. in southern Texas.

\section{Archaic Artifacts}

As in most collections in southern Texas, artifacts from the long Archaic period (6000 B.C.-A.D. 1000) are quite common. Several projectile points dating from very early within the Archaic (ca. 6000-3500 B.C.) were noted, including Bell (Fig. 15,b), Early Triangular, and Early Corner Notched (Hester 1980).

Projectile points of the Early and Middle Archaic eras (roughly 3500-1000 B.C.) include Abasolo, Tortugas, Langtry, and Shumla (heat-treated). Late Archaic points (from the time span of approximately 1000 B.C. to A.D. 1000) are much more common in the collection and consist of the following types: Catan, Carrizo (heat-treated), Desmuke. Ensor, Frio, Marcos, and Matamoros. See Hester (1980) for descriptions of these Archaic types.

Other Archaic artifacts include unifacial Clear Fork tools (including specimens made of gray quartzite; cf. Hester 1980) and bifacial Nueces tools. These cannot yet be linked to specific time periods within the Archaic. Both forms were probably used as scraping and gouging implements. One Late Archaic tool 

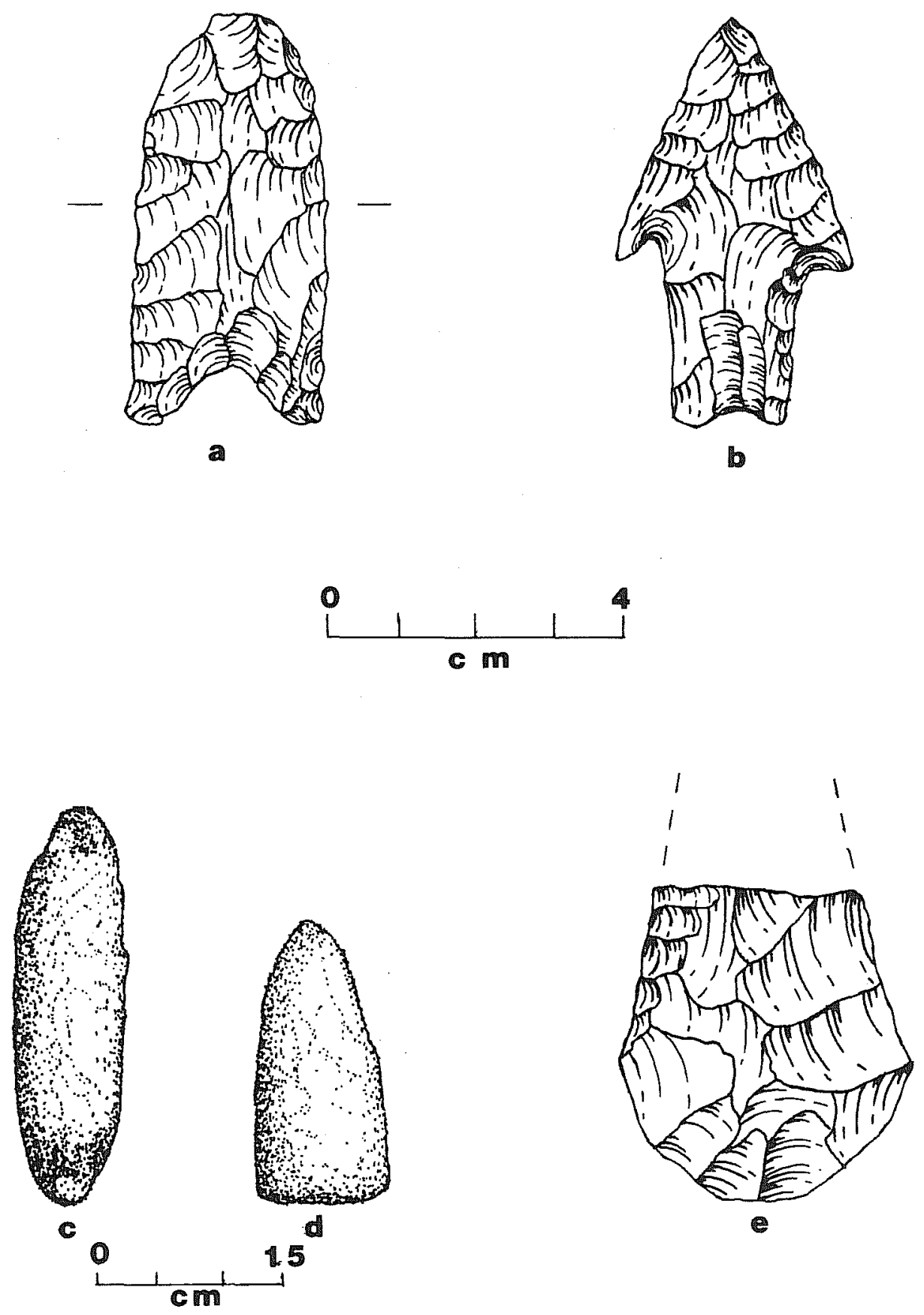

Figure 15. Artifacts from Piloncillo Ranch Collection. a, Golondrina; b, Bell; $c, d$, ground stone pestles ( $d$ is a fragment); e, fragment of beveled knife. Note different scale for $c, d$. 
noted in the collection was an example of the olmos biface form (Hester 1980). It has the ventral resharpening and burin facet typical of this tool.

Two ground stone pestles, made of dense sandstone and probably of Archaic age, were recorded and photographed (Fig. 15, C,d). Such artifacts are unusual in this region. One of the pestles is complete (28 cm long; $5.5 \mathrm{~cm}$ in diameter). The other is a fragment ( $20 \mathrm{~cm}$ long; $6 \mathrm{~cm}$ in diameter). These may have been used in conjunction with either bedrock mortars or wooden mortars for the processing of wild plant foods.

\section{Late Prehistoric Artifacts}

The Late Prehistoric period in south Texas (A.D. 1000 to Historic contact) is characterized by the appearance of the bow and arrow, certain new chipped stone tool forms, and in some areas, plain, reddish-colored pottery. Although no prehistoric ceramic fragments were seen in the collection, tiny arrow points of the Scallorn (predominant) and Perdiz types were observed. Also present was a Toyah point and a number of small side-notched or stemmed stubby triangular points of a type known as Zavala (Hester 1980). Such points are particularly common at site 41 DM 14, northwest of Catarina, not far from the Piloncillo-Valenzuela area.

One tool form of Late Prehistoric date, a fragment of a beveled knife (Fig. $15, e)$, was noted. Such artifacts are often found in bison-hunting sites of A.D. 1200-1300 in southern Texas (Hester 1980).

\section{Summary}

A review of a collection of prehistoric Indian artifacts from a number of sites in the Piloncillo Ranch area, Dimmit County, southern Texas, has revealed the presence of artifacts from all major cultural periods known in the region. The earliest specimens are from the Paleo-Indian period, roughly 8000-9000 years ago. As is typical of the region, Archaic artifacts--projectile points and tools--are most common. Unusual in this collection was the presence of two ground stone pestles. Late Prehistoric artifacts included several arrow point types, especially of the Zavala type, and a beveled knife of a form usually associated with bison-butchering activities.

A systematic survey program is needed for sites on the ranch. The materials in the present collection cannot be linked to specific sites and can thus provide only general kinds of information. However, artifacts collected under controlled conditions from properly documented sites can provide a wealth of additional information on the prehistory of the ranch area. 
References Cited

Hester, T. R.

1980 Digging Into South Texas Prehistory. Corona Publishing Co., San Antonio, Texas.

Nunley, J.P. and T. R. Hester

1966 Preliminary Archeological Investigations in Dimmit County, Texas. Texas Journal of Science 18(3):233-253. 
